\title{
An Early Jurassic braided river system from Mehadia, South Carpathians, Romania
}

\author{
Artur KĘDZIOR ${ }^{1, *}$ and Mihai Emilian POPA ${ }^{2}$ \\ 1 Polish Academy of Sciences, Institute of Geological Sciences, Twarda 51/55, 00-818 Warszawa, Poland \\ 2 University of Bucharest, Faculty of Geology and Geophysics, Laboratory of Palaeontology, 1, N. Bălcescu Ave., 010041, \\ Bucharest, Romania
}

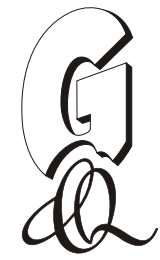

Kędzior, A., Popa, M.E., 2018. An Early Jurassic braided river system from Mehadia, South Carpathians, Romania. Geological Quarterly, 62 (2): 415-432, doi: 10.7306/gq.1415

Associate editor: Anna Wysocka

The Lower Jurassic (Hettangian-Sinemurian) continental deposits of the Mehadia area (Caraş-Severin County) belong to the Presacina Basin, Upper Danubian Units of the South Carpathians, Romania. This un-named succession is exposed along large areas within the Greatca Quarry where deposits of a complex braided river system can be seen. Nine clastic facies are identified within the Mehadia section and grouped into two facies associations reflecting two main sub-environments. (A) a fine-grained association, up to $6.5 \mathrm{~m}$ thick, composed of greyish black and dark grey massive and horizontally laminated mudstones interbedded with fine- to medium-grained sandstones showing ripple lamination, tabular low-angle large-scale cross-bedding and in some places massive sandstones. Within this association coarsening and fining-upward sequences are visible, while subordinate pensymmetrical-like sequences were observed. The sediments of the fine-grained association are interpreted as having been deposited along an alluvial plain from flood waters. The sandstone interbeds are interpreted as crevasse channel-fills and the thinner sandstone bodies as proximal crevasse splays. (B) a coarse-grained facies association represented by sandstones and conglomerates, both clast- and matrix-supported, from granule to pebble clast sizes. Almost all basal members of this association are underlain by erosional surfaces, while internal erosional surfaces occur at some levels. The coarse-grained facies association is interpreted as having been deposited within active river channels of a sandy braided river system. The occurrence of numerous erosional surfaces, the recurrence of the facies within this association (channel bodies), as well as the abundant mudstone and sandstone intraclasts all point to frequent conditions of erosion (including redeposition) of previously deposited sediments. The relatively low fine-grained sediment content $(<25 \%)$ can be explained by two factors: (1) a creation rate for accommodation space was not enough for the accumulation of a large amount of overbank deposits; (2) a lack of larger quantities of fine-grained material being transported in the river system. Both factors may have operated independently or interacted.

Key words: sedimentology, Lower Jurassic, continental deposits, Mehadia, South Carpathians, Romania.

\section{INTRODUCTION}

The Lower Jurassic terrestrial formations of the South Carpathians represent an important field of investigation because of their coal reserves, key palaeobotanical and palaeozoological contents and the significance of their sedimentology and palaeogeography (Popa and Van Konijnenburg-Van Cittert, 2006; Popa, 2009; Kędzior and Popa, 2013). Along the northern border of the Tethys realm, the Lower Jurassic coal-bearing deposits of the South Carpathians show sedimentological, palaeontological and palaeoclimatic features which can be studied within extended underground

*Corresponding author, e-mail: ndkedzio@cyf-kr.edu.pl

Received: March 1, 2017; accepted: February 1, 2018; first published online: May 14, 2018 mines or opencast mines (Popa and Van Konijnenburg-Van Cittert, 2006; Popa, 2009).

The Mehadia area is located in the South Carpathians, Caraş-Severin County, north of Orşova and Topleţ, within the Presacina Basin. It belongs tectonically to the Danubian Units (Codarcea, 1940), and more precisely to the Internal or Upper Danubian Units (Fig. 1; Berza et al., 1983, 1994; Mutihac, 1990; lancu et al., 2005). The deposits of the Mehadia area were studied along the Greaca Valley, a left tributary of the Belareca River in Mehadia (spelled also Bela Reca, Bella Reca, or Bella Recca), within a quarry on the eastern side of the town (Fig. 2A-D). To the eastern end of the quarry occurs the confluence between the Greaţca and Ciumoasa valleys. Immediately south of the quarry there is the Străjuţ peak, represented by Permian rocks, which are mainly rhyolites.

The first geological studies in the Mehadia area were undertaken by Schloembach (1869), Schafarzik (1885, 1886, 1889) and Schreter (1911), who briefly described the local geology. Modern studies of the South Carpathians and of the Mehadia area were published first by Codarcea (1940), who detailed the 


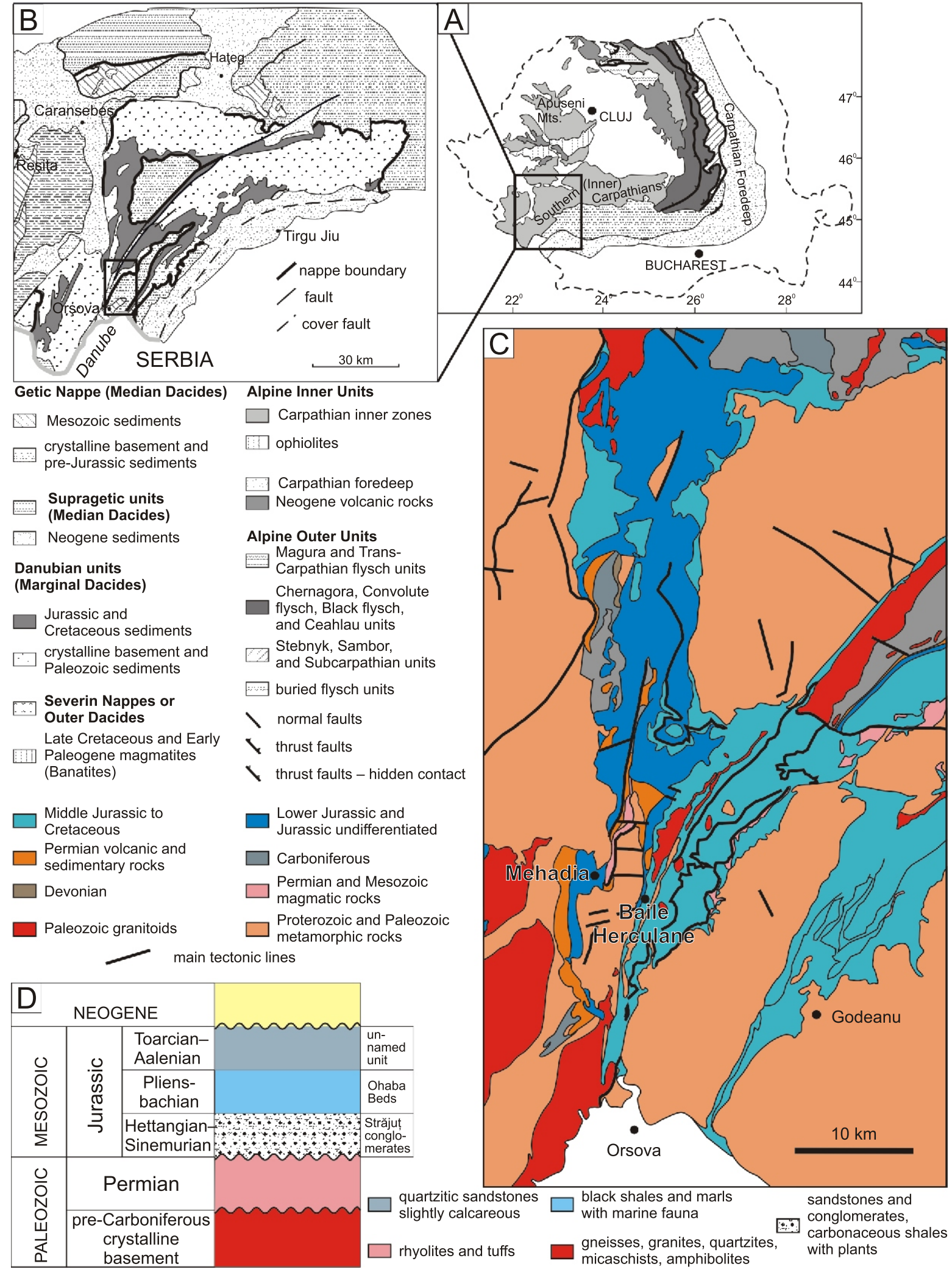

Fig. 1A-D - geological setting of the Mehadia area, as part of the geological structure of the South Carpathians, in the Upper Danubian Units, Presacina Basin 

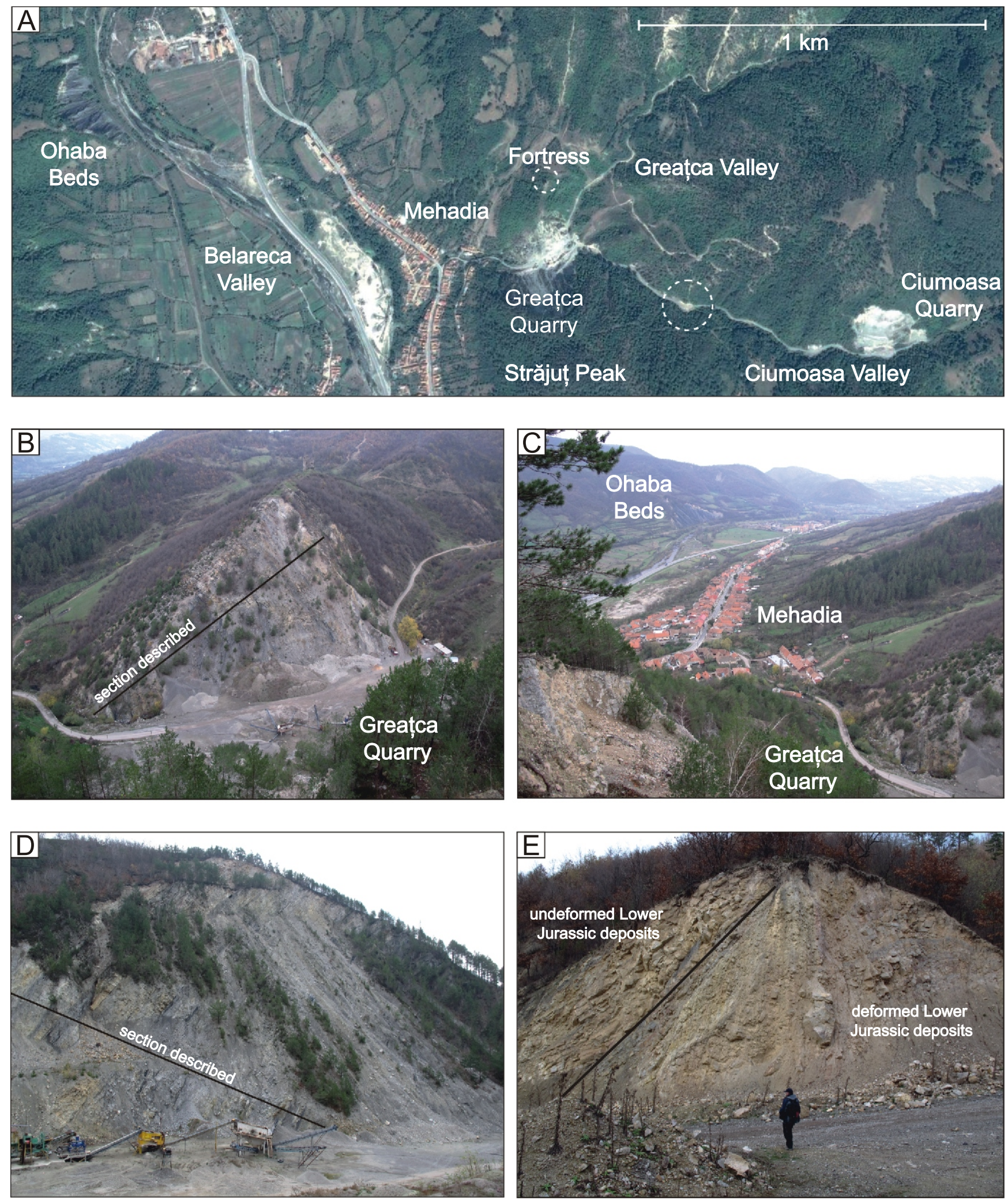

Fig. 2. Mehadia area, exposures and quarries

A - satellite view, the dotted circle marks the exposure figured here in Figure 2E; B - northern flank of the Greaţca Quarry, base of succession to the left (West), top to the right (East); C - western end of the Greatca Quarry (entrance), Mehadia town and the outcrop of the Ohaba Beds, Pliensbachian-Toarcian in age; D - southern flank of the Greacţa Quarry, base of succession to the right (West), top to the left (East); E - Lower Jurassic deposits in an exposure along the Ciumoasa Valley (circled in Fig. 2A) 
tectonic structure and the stratigraphy of all the tectonic units of the South Carpathians, after Munteanu-Murgoci (1905) had identified the Getic Nappe. The local geology was detailed by Gheorghiu and Răileanu (1957), Gheorghiu (1958), Iliescu and Semaka (1962), Iliescu (1963), lliescu et al. (1968), Semaka (1969, 1970), Nãstãseanu (1980) and Nãstãseanu and Cernjavska (1980) who described the Jurassic sedimentary successions of Mehadia, including the fossil fauna, macroflora and microflora.

Gheorghiu and Răileanu (1957) briefly discussed the continental succession, characterizing it as belonging to the Gresten facies and dating it as not younger than Pliensbachian. They dated black, bituminous shales, considered to be overlying conglomeratic-sandy deposits, outcropping along the Belareca Valley as Middle Liassic (Pliensbachian-Toarcian) in age. They defined the conglomeratic sequence as the "Străjut conglomerates", with quartz clasts and reworked Permian rhyolites and red sandstones. Gheorghiu (1958) detailed the geology of the Toplet-Mehadia area, briefly describing the Lower Jurassic sequences, with basal conglomerates, siliceous sandstone, whitish fossiliferous marls and black shales.

Iliescu and Semaka (1962), Iliescu (1963) and Semaka $(1969,1970)$ cited a series of fossil plants collected from sandstone interlayers of the basal conglomerates along the Greaţca Valley and considered the lower part of the basal conglomerates to be Rhaetian. Iliescu et al. (1968) based on the occurrence of various plant species also considered the base of the succession to be Rhaetian. These authors identified Phlebopteris angustiloba, Todites denticulata, Marattiopsis hoerensis, Williamsonia gigas, Nilssonia polymorpha, Ginkgoites marginatus, Stachyotaxus elegans and S. sp. (original names of taxa cited here), most probably collected from precisely the same fossiliferous levels we studied in 2012 and 2013. They named the succession as "the angustiloba beds" and the occurrence of Stachyotaxus elegans, Phlebopteris angustiloba and Marratiopsis hoerensis were considered by these authors as a proof for the Rhaetian age of the basal conglomeratic succession from the Greaţca Valley.

lliescu et al. (1968) collected, from an upper, sandstone succession in Greaţca Valley, the fern Todites denticulata and brachiopods such as Rhynchonella variabilis and Spiriferina sp., and considered them to be Hettangian-Sinemurian in age. They synonymized the "Străjut beds" with the "angustiloba beds", dating them as strictly Rhaetian for the whole conglomeratic succession along the Greaţca Valley.

Nãstãseanu (1980) undertook detailed palaeontological studies, with some sedimentological observations, regarding the Lower Jurassic successions in the Mehadia area, and discussed their facies variations and local structures together with their fossils of fauna, macro- and microflora. Nãstãseanu considered the thickness of these deposits to be up to $1100 \mathrm{~m}$ thick, and the Lower Jurassic deposits with the Gresten features to be $550-800 \mathrm{~m}$ thick. The Hettangian-Sinemurian was described as $200-300 \mathrm{~m}$ in thickness, with a basal conglomeratic horizon and a sandy horizon. The Pliensbachian-Toarcian deposits belong to the "Ohaba beds", being represented mainly by fossiliferous black shales said to be a lateral facies of the "Bogâltin beds". Nãstãseanu described the Aalenian as represented by the "Ciumârna beds".

Nãstãseanu and Cernjavska (1980) also detailed and illustrated a Hettangian microfloral assemblage along the Greaţca and Ciumoasa valleys, which were regarded as indicators for the Lower Jurassic (Hettangian-Sinemurian) in Mehadia, thereby rejecting the Rhaetian age proposed by previous authors. They considered the local Greaţca-Ciumoasa structure with Lower Jurassic conglomerates as a local syncline, oriented west-east, with its axis east of and close to the Greaţca-Ciumoasa confluence. The western flank of this syncline is limited by the Mehadia-Cornereva Fault, while the eastern flank is expressed along the Ciumoasa Valley as an unconformity between the Hettangian and the Permian deposits. Nãstãseanu and Cernjavska (1980) described the thickness of the succession as $200 \mathrm{~m}$.

The aim of this study is to document the depositional record from one of the largest outcrops of Lower Jurassic continental strata from the Upper Danubian unit of the South Carpathians. A description and interpretation of the sedimentary facies also helps the understanding of the drainage pattern for the earliest Jurassic. The analysis represents a case study of a Lower Jurassic coarse-grained fluvial succession and illustrates the temporal environmental and, on a limited scale, the spatial changes of the sedimentary environments.

\section{GEOLOGICAL BACKGROUND}

The Lower Jurassic continental succession of the Mehadia area uncomfortably overlies the metamorphic rocks of the Danubian basement (Neamţu series) or the Permian volcano-sedimentary successions, and is itself uncomfortably overlain by Miocene strata.

The Lower Jurassic deposits of the Mehadia area are outlined in the following succession:

1. A basal conglomeratic, terrestrial succession, with sandstone and mudstone interlayers, known as "the Străjut conglomeratic beds", or "the angustiloba beds", 50-300 $\mathrm{m}$ in thickness, is exposed mainly in the Greaţca Quarry. The succession in the Mehadia area (Greaţca and Ciumoasa valleys) is the subject of this paper. At its top occur siliceous, white, conglomerates and sandstones, conformably overlying the basal conglomerates, $\sim 75 \mathrm{~m}$ thick. This succession is Hettangian-Sinemurian in age;

2. Black, bituminous, fossiliferous shales, locally grey-whitish and marly at their base, conformably overlie the siliceous sandstone succession, and are also known as the "black Liassic series", the "Ohaba beds" (Fig. 2A, C) and the "Bogâltin beds". This marly and bituminous succession is $350-400 \mathrm{~m}$ thick where it grades into black, bituminous shales which outcrop especially along the right bank of the Belareca River in Mehadia (along the railways, where they offer a large, fossiliferous exposure). In this paper the succession is considered to be Pliensbachian-Toarcian in age, with part of it being related to the Early Toarcian oceanic anoxic event (T-OAE).

Within the Greaţca Quarry, the Lower Jurassic terrestrial beds dip eastwards at $50-60^{\circ}$. This attitude changes after the confluence between the Greaţca and Ciumoasa valleys, where the strata can even be horizontal. Also beds dipping westwards can be observed $\sim 270 \mathrm{~m}$ upstream from the confluence, along the Ciumoasa Valley. This is where Nãstãseanu and Cernjavska (1980) showed the unconformity between the Hettangian and Permian successions, and the occurrence of their first samples (their fig. II illustrated here in our Fig. 2A and E). We consider this exposure to show the tectonic contact between the Hettangian and Permian deposits, not necessary as an unconformity (Fig. 2E). The Lower Jurassic deposits along the Ciumoasa Valley are strongly tectonised upstream from the confluence between Greaţca and Ciumoasa, making it difficult to assess what might be a monocline or a syncline in the area. Along Greaţca Quarry, up to the confluence between the 
Greaţca and Ciumoasa valleys, the lower Jurassic deposits have monoclinal positions, being interpreted as either belonging to a single monocline or to the western flank of a syncline.

We refrain from formally naming a new formation for the Hettangian-Sinemurian strata of the Mehadia area. They have been previously named as the "angustiloba beds", as well as the "Străjuţ conglomerates", but both their base and top are missing in the area, making a formal stratigraphic assessment difficult. The most appropriate name for the studied succession is the "Schela Sandstone Formation", which has been described previously from the Danubian Units (Mrazec, 1898; Manolescu, 1932; Drăghici and Boiciuc, 1969; Nãstãseanu et al., 1981) and shows no facies and palaeobotanical differences from the Mehadia section.

\section{MATERIAL AND METHODS}

Fieldwork was undertaken during the autumns of 2012 and 2013 when detailed mapping and sampling were carried out in the Mehadia area, and especially along the Greaţca and Ciumoasa valleys. The lithofacies classification was produced using the successional description at 1:100 scale. The successional description includes the lithology, the textures and the structures of the sedimentary rocks, fossil occurrences and their orientation, bioturbation, rock colour, faults and tectonoglyphs. The combination of macroscopic lithological, structural, textural and biotic features were used for subdividing the lithofacies and lithofacies associations. Drawings were made and photographs taken while beds were counted and measured, recorded and sampled and the sedimentary structures documented through the Hettangian-Sinemurian succession. Each layer was recorded, counted, measured and photographed, in order to obtain a highly precise and detailed sedimentological and palaeontological image of the sedimentary successions.

\section{RESULTS}

The sedimentary succession of the studied Mehadia area is $>200 \mathrm{~m}$ thick and is well exposed along both sides of a former opencast mine for sandstones and gravels, located within the Greaţca Valley, downstream of its confluence with the Ciumoasa Valley. The valley mouth has been widened giving fresh exposures of part of the succession.

\section{LITHOFACIES DESCRIPTION AND INTERPRETATION}

Nine lithofacies are distinguished and described in order of increasing grain-size (Table 1) and the net content of the individual lithofacies is shown in Figure 3A. This simple comparison of the net content leads to a conclusion that the sandy and conglomeratic lithofacies ( $\mathrm{Sr}, \mathrm{SI}, \mathrm{Sm}, \mathrm{Gm}$ and $\mathrm{Gc})(75 \%)$ predominate over the fine-grained lithofacies (MM, Mh, MD and Srr) $(\sim 25 \%)$.

Massive mudstones (Mm). This lithofacies is represented by greyish black to medium dark grey mudstones and claystones with no clearly visible sedimentary structures (Fig. 4A) ranging in thickness between $3-30 \mathrm{~cm}$ and up to $50 \mathrm{~cm}$ (Fig. 3B) as they form interbeds within sandy or gravel deposits. Boundaries with the surrounding deposits are both gradational and sharp, but there is no clear regularity in the type of underlying deposits. In many cases these are fine-grained sandstones, but sometimes there are coarse-grained sandstones or even conglomerates. Some traces of root systems and plant remains were recorded including coal-coated holes which are typical remnants of stems in growth position. In one place desiccation crack-like structures were observed. The upper boundaries are usually sharp or erosional.

This lithofacies was proposed by Miall (1977) for the mud drapes occurring within sandy and gravelly braided deposits, where they represent either sediments accumulating in pools of standing water during low-stage channel abandonment or the most distal floodplain facies, including deposition in floodplain ponds (Rust, 1978).

Horizontally laminated mudstones (Mh). This is represented by greyish black to medium dark grey mudstones and claystones with a subtle horizontal lamination (Fig. 4B). They are marked by thin, sub-millimetric lenses and laminae of coarser material. This lithofacies varies in thickness between $1-60 \mathrm{~cm}$, but almost $50 \%$ of the horizontally laminated mudstones has a thickness $<10 \mathrm{~cm}$ (Fig. 3C). The basal and top boundaries are sharp if the lithofacies is embedded in medium to very coarse-grained sandstones. A gradational lower boundary has been observed if massive and ripple-laminated fine-grained sandstones occur below the horizontally laminated mudstones. These sandstones contain traces of root systems. The upper boundary in many cases is erosional. This lithofacies, with well-preserved root systems and compression fossil flora, is typical of overbank areas and it represents deposition from suspension and weak tractional currents.

Diamictites (MD). This lithofacies includes both massive and horizontally laminated grayish black to dark gray mudstones, but its specific feature is the occurrence of dispersed quartz grains and clasts up to $2 \mathrm{~cm}$ across (Fig. 4C, D), which are subangular to subrounded and chaotically distributed within the mudstone matrix. The term "diamictite" (Frakes, 1978 ) is preferred, emphasizing only a range of particle sizes, not a "relative abundance of any or all size classes". This lithofacies in not very common overall and its thickness does not exceed $50 \mathrm{~cm}, 80 \%<30 \mathrm{~cm}$ (Fig. 3D). Its boundaries are mostly sharp, although the upper boundary locally shows erosional features. The surrounding deposits are nearly always coarse to very coarse-grained sandstones or conglomerates; only occasionally this lithofacies is underlain by mudstones (Mm or Mh) and fine-grained sandstones.

The massive quartz-bearing mudstones represent sediments generated in pools of standing water during low-stage channel abandonment phases, whereas the laminated mudstones were formed in overbank areas with their deposition being influenced by suspension and weak tractional currents. The presence of scattered quartz clasts can be explained by several different mechanisms.

The first involves the quartz clasts being attached to the roots of plants that had been growing on the topmost parts of vegetated bars that are composed of sandstones with dispersed pebbles or conglomerates. During the next high water level, the trunks were washed out as floating debris and pebbles sunk as the heaviest particles. The second possibility involves high-viscosity flows, which are able to carry almost all clasts and then deposit massive and chaotic sediments. However, as such a mechanism needs steep slopes to generate debris flows, deposition could have taken place following phases of erosion of banks that were composed of cohesive material possibly stabilized by a dense root network. Another explanation of the occurrence of diamictites relates to the migration of bars on a muddy substrate. The gravels rolling down the slipface may have formed layers within the mud (Fig. 4D) or become chaotically dispersed within it (Fig. 4C) with mud infilling the spaces between clasts (Dashtgard et al., 2006). The limited exposure of the diamictite layers means that the muddy sub- 
Table 1

Lithofacies of the Schela Formation in the Mehadia section

\begin{tabular}{|c|c|c|c|c|c|c|c|c|}
\hline Lithofacies & Lithology & $\begin{array}{l}\text { Sedimentary } \\
\text { structures }\end{array}$ & Internal features & Fossils & Contacts & Thickness & $\begin{array}{l}\% \text { content } \\
\text { in succession }\end{array}$ & Interpretation \\
\hline $\begin{array}{l}\text { Massive } \\
\text { mudstones } \\
(\mathrm{Mm})\end{array}$ & $\begin{array}{l}\text { greyish black to } \\
\text { medium dark } \\
\text { grey mudstones } \\
\text { and claystones }\end{array}$ & \begin{tabular}{|l|} 
no clearly visible \\
sedimentary structures, \\
very rarely desiccation \\
crack-like structures
\end{tabular} & $\begin{array}{l}\text { interbeds within sandy or } \\
\text { gravelly deposits }\end{array}$ & $\begin{array}{l}\text { traces } \\
\text { of root } \\
\text { systems } \\
\text { and plant } \\
\text { remains }\end{array}$ & $\begin{array}{l}\text { both gradational } \\
\text { and sharp }\end{array}$ & $\begin{array}{l}<50 \mathrm{~cm} \text {, } \\
\text { usually } \\
\text { ranges } \\
\text { between } \\
3-30 \mathrm{~cm}\end{array}$ & 9 & $\begin{array}{l}\text { pools of standing water } \\
\text { during low-stage } \\
\text { channel abandonment or } \\
\text { the most distal floodplain } \\
\text { facies, including deposition in } \\
\text { floodplain ponds (Rust, 1978) }\end{array}$ \\
\hline $\begin{array}{l}\text { Horizontally } \\
\text { laminated } \\
\text { mudstones } \\
\text { (Mh) }\end{array}$ & $\begin{array}{l}\text { greyish black to } \\
\text { medium dark } \\
\text { grey mudstones } \\
\text { and claystones }\end{array}$ & $\begin{array}{l}\text { subtle } \\
\text { horizontal } \\
\text { lamination }\end{array}$ & $\begin{array}{l}\text { with thin, sub-millimetre } \\
\text { lenses and laminae of } \\
\text { coarser material or } \\
\text { foliation parallel to } \\
\text { bedding plane }\end{array}$ & \begin{tabular}{l|} 
\\
well \\
developed \\
and \\
preserved \\
root systems; \\
determinable \\
leafy flora
\end{tabular} & \begin{tabular}{|l|} 
sharp if embedded \\
between medium- \\
to very coarse-grained \\
sandstones; gradational \\
lower boundary with \\
transition from fine- \\
grained sandstones; \\
upper boundary \\
mainly erosional \\
\end{tabular} & $\begin{array}{l}1-60 \mathrm{~cm} \\
\text { mainly } \\
<10 \mathrm{~cm}\end{array}$ & 12 & $\begin{array}{l}\text { deposition from } \\
\text { suspension and weak } \\
\text { traction currents } \\
\text { in overbank areas }\end{array}$ \\
\hline $\begin{array}{l}\text { Diamictites } \\
\quad \text { (MD) }\end{array}$ & $\begin{array}{l}\text { greyish black to } \\
\text { medium dark } \\
\text { grey mudstones } \\
\text { with scattered } \\
\text { clasts }\end{array}$ & $\begin{array}{l}\text { massive and } \\
\text { horizontally } \\
\text { laminated }\end{array}$ & $\begin{array}{l}\text { subangular to subrounded } \\
\text { granule- to pebble-sized } \\
\text { clasts chaotically } \\
\text { distributed within } \\
\text { mudstone matrix }\end{array}$ & none & $\begin{array}{l}\text { mostly sharp, sometimes } \\
\text { the upper boundaries } \\
\text { with erosional features }\end{array}$ & $\begin{array}{l}<50 \mathrm{~cm} \text {, } \\
\text { usually } \\
\text { thinner } \\
\text { than } \\
30 \mathrm{~cm}\end{array}$ & 4 & $\begin{array}{l}\text { debris flow created by } \\
\text { cutting banks } \\
\text { composed of cohesive } \\
\text { material or stabilized by } \\
\text { dense root network }\end{array}$ \\
\hline $\begin{array}{l}\text { Root- } \\
\text { reworked } \\
\text { sediments } \\
\quad(\text { Srr })\end{array}$ & $\begin{array}{l}\text { mudstones and } \\
\text { fine-to } \\
\text { medium-grained } \\
\text { sandstones }\end{array}$ & massive & $\begin{array}{l}\text { original sedimentary } \\
\text { structures are blurred, } \\
\text { obscured or destroyed } \\
\text { by root networks and } \\
\text { bioturbation }\end{array}$ & $\begin{array}{l}\text { coalified } \\
\text { dense } \\
\text { root } \\
\text { systems }\end{array}$ & $\begin{array}{l}\text { lower boundaries usually } \\
\text { gradational, upper } \\
\text { boundaries sharp or } \\
\text { having erosional features }\end{array}$ & $\begin{array}{l}5-60 \mathrm{~cm} \\
\text { usually } \\
<25 \mathrm{~cm}\end{array}$ & 2 & $\begin{array}{l}\text { vegetated floodplains, } \\
\text { including natural levee } \\
\text { areas, and represents } \\
\text { soil development in a } \\
\text { humid climate }\end{array}$ \\
\hline $\begin{array}{l}\text { Ripple- } \\
\text { laminated } \\
\text { sandstones } \\
\quad(\mathrm{Sr})\end{array}$ & \begin{tabular}{l|} 
medium dark \\
grey to grey \\
fine- and \\
medium-grained \\
sandstones
\end{tabular} & $\begin{array}{l}\text { asymmetrically } \\
\text { inclined } \\
\text { laminae }\end{array}$ & $\begin{array}{l}\text { lamination } \\
\text { marked by silt } \\
\text { admixture or fine } \\
\text { plant detritus }\end{array}$ & none & $\begin{array}{l}\text { lower boundaries usually } \\
\text { gradational, sometimes } \\
\text { sharp, if underlain by } \\
\text { mudstones; upper } \\
\text { boundaries gradational, } \\
\text { sharp or erosional if } \\
\text { overlain by the coarsest } \\
\text { sediments }\end{array}$ & $\begin{array}{l}3-70 \mathrm{~cm}, \\
\text { usually }<30 \mathrm{~cm} \text {; } \\
\text { individual sets } \\
\text { thickness } \\
\text { up to } 3 \mathrm{~cm} ; \\
\text { cosets } \\
\text { thickness } \\
<35 \mathrm{~cm}\end{array}$ & 9 & $\begin{array}{l}\text { migration of small ripples in } \\
\text { conditions of lower flow regime }\end{array}$ \\
\hline $\begin{array}{l}\text { Large scale } \\
\text { cross- } \\
\text { bedded } \\
\text { sandstones } \\
\text { (SI) }\end{array}$ & $\begin{array}{l}\text { medium dark } \\
\text { grey to grey } \\
\text { medium- to } \\
\text { very coarse- } \\
\text { grained } \\
\text { sandstones and } \\
\text { conglomerates }\end{array}$ & $\begin{array}{l}\text { low-angle tabular } \\
\text { cross-stratification; } \\
\text { only three } \\
\text { sandstone beds } \\
\text { undoubtedly through- } \\
\text { cross-bedded }\end{array}$ & $\begin{array}{l}\text { dip of laminae varies from } \\
1.5 \text { up to } 11 \text { degrees, } \\
\text { sporadically exceeds } 15^{\circ}, \\
\text { usually asymptotic } \\
\text { contact with bounding } \\
\text { surfaces }\end{array}$ & none & $\begin{array}{l}\text { lower boundaries usually } \\
\text { gradational, erosional if } \\
\text { undrelain by mudstones } \\
\text { lithofacies; upper } \\
\text { boundaries gradational, } \\
\text { sharp if overlain by Mm } \\
\text { and Mh lithofacies; } \\
\text { erosional if overlain by } \\
\text { conglomerates }\end{array}$ & $\begin{array}{l}3-440 \mathrm{~cm} \text {, usually } \\
10-100 \mathrm{~cm} ; \\
\text { laminae-sets } \\
\text { thicknesses } \\
\text { up to several } \\
\text { decimetres; } \\
\text { co-sets } \\
\text { thicknesses } \\
\text { up to several } \\
\text { metres }\end{array}$ & 28 & $\begin{array}{l}\text { washed-out dunes and humpback } \\
\text { dunes occurring at the transition } \\
\text { between subcritical and } \\
\text { supercritical unidirectional flow }\end{array}$ \\
\hline $\begin{array}{l}\text { Massive } \\
\text { sandstones } \\
\quad(\mathrm{Sm})\end{array}$ & $\begin{array}{l}\text { conglomeratic } \\
\text { to fine-grained } \\
\text { sandstones }\end{array}$ & massive & $\begin{array}{l}\text { in mesoscopic and } \\
\text { macroscopic scale, } \\
\text { no sedimentary } \\
\text { structures distinguished }\end{array}$ & none & $\begin{array}{l}\text { local erosional surfaces } \\
\text { at the contact of } \\
\text { similar fraction }\end{array}$ & $\begin{array}{l}\text { from few } \\
\text { centimetres } \\
\text { up to } 3.5 \mathrm{~m}\end{array}$ & 25 & $\begin{array}{l}\text { hyperconcentrated flow } \\
\text { resulted from torrential flood; } \\
\text { abrupt aggradation of the } \\
\text { upper plane bed }\end{array}$ \\
\hline $\begin{array}{l}\text { Clast- } \\
\text { supported } \\
\text { conglo- } \\
\text { merates } \\
\text { with } \\
\text { abundant } \\
\text { matrix } \\
(\mathrm{Gm})\end{array}$ & conglomerates & $\begin{array}{l}\text { massive, poorly } \\
\text { visible planar and } \\
\text { cross-bedding }\end{array}$ & $\begin{array}{l}\text { poorly sorted } \\
\text { conglomerates } \\
\text { composed of } \\
\text { quartz, chert, quartzite } \\
\text { granules and pebbles, } \\
\text { mudstone and } \\
\text { fine-grained sandstone } \\
\text { intraclasts up to } \\
10 \mathrm{~cm} \text { long }\end{array}$ & none & $\begin{array}{l}\text { lower boundaries usually } \\
\text { erosional, sharp upper } \\
\text { boundaries if the distinct } \\
\text { lithological contrast, } \\
\text { gradational if with faint } \\
\text { grain-size variations }\end{array}$ & $\begin{array}{l}5 \mathrm{~cm} \text { to } 4 \mathrm{~m} \\
\text { usually } \\
>30 \mathrm{~cm}\end{array}$ & 7 & $\begin{array}{l}\text { high-energy braided river with } \\
\text { gravelly longitudinal bars, } \\
\text { deposition during flash floods }\end{array}$ \\
\hline $\begin{array}{l}\text { Clast- } \\
\text { supported } \\
\text { conglo- } \\
\text { merates } \\
\text { (Gc) }\end{array}$ & conglomerates & $\begin{array}{l}\text { massive or } \\
\text { horizontal } \\
\text { stratification }\end{array}$ & $\begin{array}{l}\text { well and poorly sorted } \\
\text { conglomerates } \\
\text { composed of } \\
\text { quartz, chert, quartzite } \\
\text { granules and pebbles, } \\
\text { mudstone and } \\
\text { fine-grained sandstone } \\
\text { intraclasts up to } \\
10 \mathrm{~cm} \text { long }\end{array}$ & none & $\begin{array}{l}\text { lower boundaries usually } \\
\text { erosive, sharp or even } \\
\text { gradational in the places } \\
\text { of the small grain-size } \\
\text { change; upper } \\
\text { boundaries } \\
\text { mostly gradational }\end{array}$ & $\begin{array}{l}2 \mathrm{~cm} \text { (almost } \\
\text { single lamina) } \\
\text { up to } 80 \mathrm{~cm} \text {, } \\
\text { only one layer } \\
>1 \mathrm{~m}\end{array}$ & 4 & $\begin{array}{l}\text { thin lags and/or } \\
\text { longitudinal bars } \\
\text { in braided river } \\
\text { channel }\end{array}$ \\
\hline
\end{tabular}



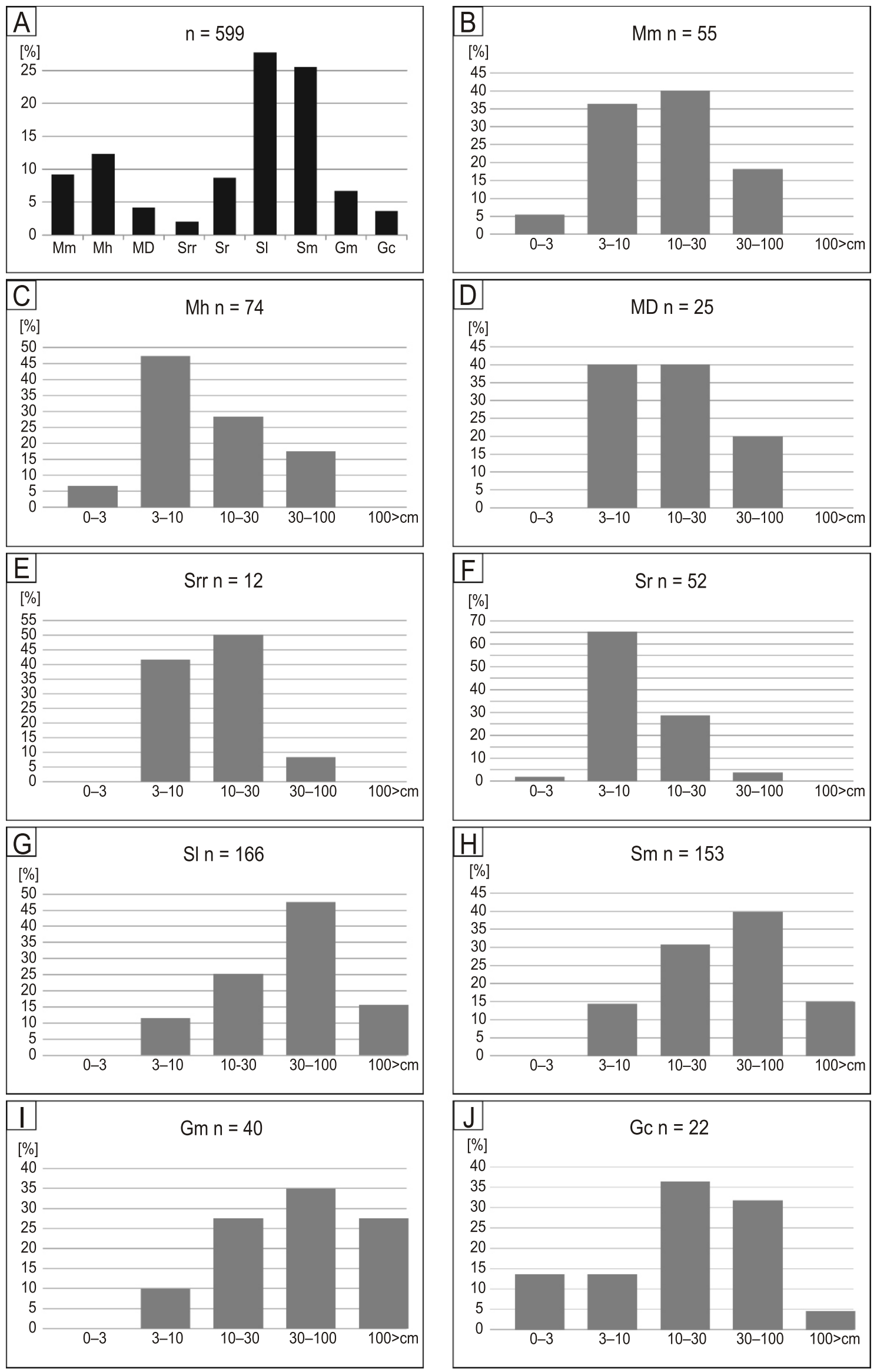

Fig. 3. Contents of the individual lithofacies and their thickness distribution 

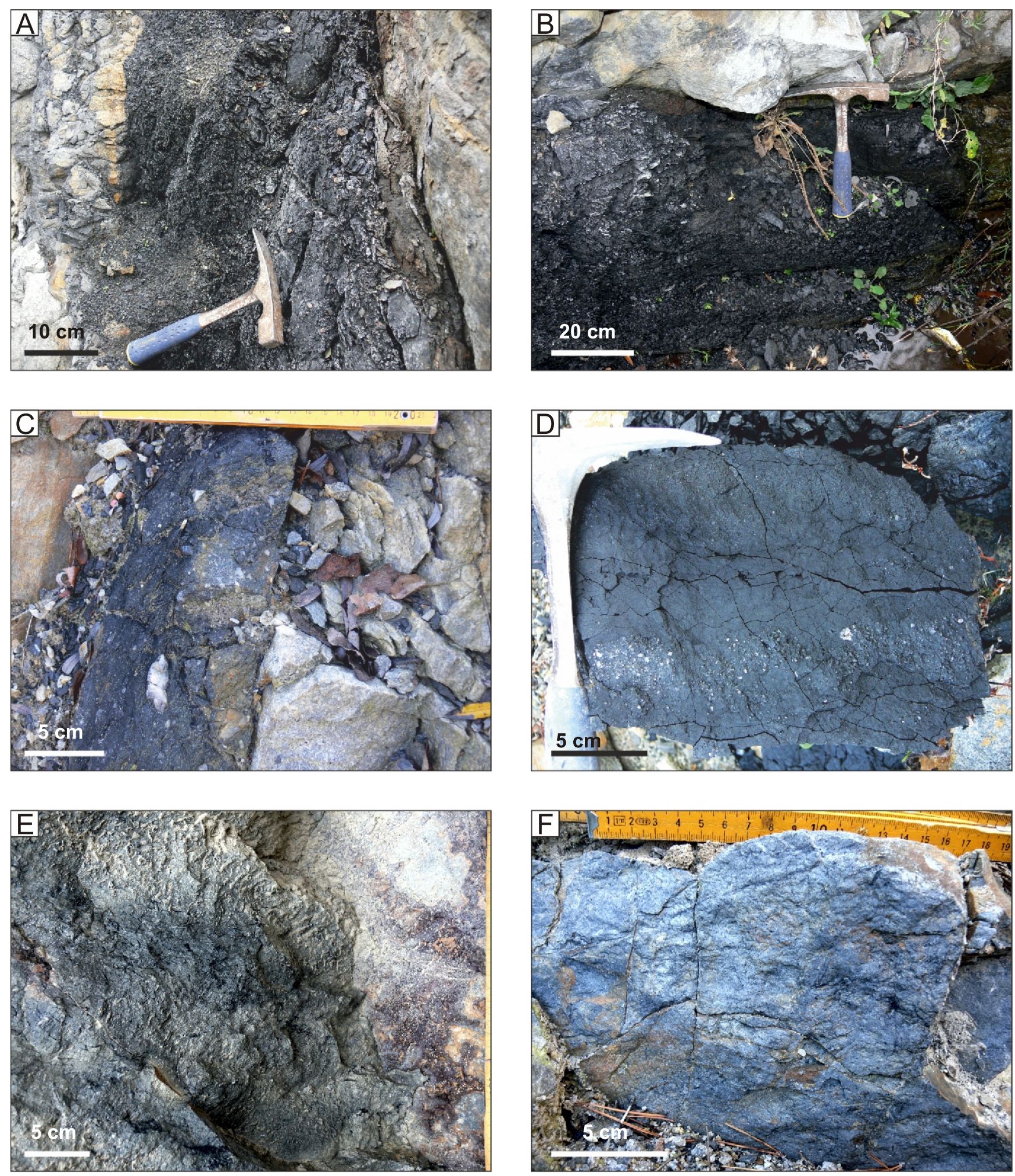

Fig. 4. Fine-grained lithofacies

A - massive mudstone $(\mathrm{Mm})$ lithofacies; B - horizontally laminated mudstone (Mh) lithofacies overlain by massive sandstones (Sm lithofacies) with erosional surface at the base; C, D - diamictites (MD) lithofacies: C - dispersed poorly sorted (pebble to granule size) quartz grains; D - well-sorted granule size quartz grains; E, F - root-reworked sediments (Srr) lithofacies: E - bedding surface view; F perpendicular to bedding surface view 

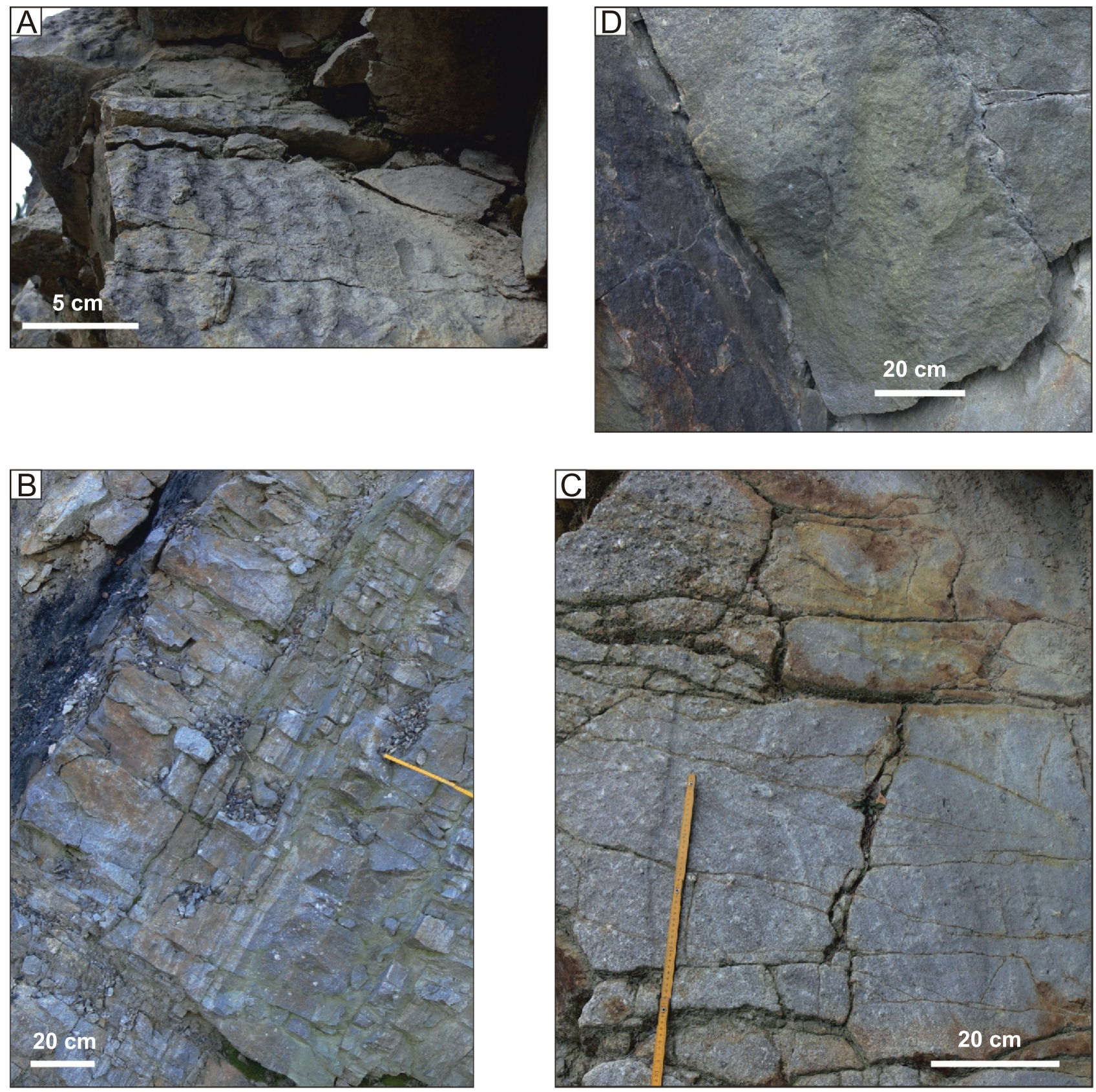

Fig. 5. Sandstone lithofacies

A - ripple-laminated sandstone (Sr) lithofacies, bedding surface view; B, C - large-scale cross-bedded sandstone (SI) lithofacies: B very coarse-grained sandstone with faint tabular cross-bedding; C - parting lineation - bedding surface view; D - massive sandstone (Sm) lithofacies with sharp boundary of overlying SI lithofacies

stratum might represent an infill of gullies developed on top of the channel bars or abandoned channels.

Root-reworked sediments (Srr). This lithofacies includes both mudstones and fine- to medium-grained sandstones. It is rare in the section studied and only 12 levels of this type were found. The original sedimentary structures are blurred, obscured or destroyed by root networks and bioturbation (Fig. 4E, $\mathrm{F}$ ) and a single remnant of a stem in a growth position has been found. The thickness of this lithofacies ranges between $5-60 \mathrm{~cm}$, but usually it is $<25 \mathrm{~cm}$ (Fig. 3E). The lower boundaries are usually gradational if they overlie ripple-laminated to cross-bedded sandstones. The upper boundaries are sharp or have erosional features. This lithofacies is common on vege- tated floodplains, including natural levee areas, and represents soil development in a humid climate.

Ripple-laminated sandstones (Sr). This lithofacies is represented by medium dark grey to grey fine- and medium-grained sandstones with asymmetrical ripples (Fig. 5A). The lamination is typically marked by silt admixture or fine plant detritus. The thickness of the individual sets varies from a few millimetres up to $3 \mathrm{~cm}$. The coset thickness attains not more than $35 \mathrm{~cm}$ (Fig. 3F). The deposits of this lithofacies usually pass gradationally from coarser deposits of the SI lithofacies, although locally the lower boundary is sharp if they are underlain by mudstones of the Mh and Mm lithofacies. The lithofacies is followed by $\mathrm{Mh}$ and $\mathrm{Mm}$ lithofacies, but sporadically a coars- 
ening-upwards depositional sequence occurs, and in such cases the $\mathrm{Sr}$ lithofacies is overlain by cross-bedded sandstones. In the coarsest ripple-laminated sandstones the boundary between lithofacies is accentuated with sharp or even erosional surfaces. The Sr lithofacies is related to the migration of small ripples in conditions of relatively low-energy flows (lower flow regime).

Large-scale cross-bedded sandstones (SI). This lithofacies is the most common in the whole succession (28\%). Deposits with inclined internal stratification are typical, with the majority having low-angle cross-bedded features with only three beds being trough cross-bedded. The dip varies from $1.5^{\circ}$ up to $11^{\circ}$ and only in two cases exceeds $15^{\circ}$, usually with asymptotic contacts with bounding surfaces. Low angle cross-bedding is commonly visible, being emphasized by the occurrence of inclined coarser material stringers. The dominant type of the cross-bedding occurs in a broad range of grain sizes, from conglomeratic to medium-grained sandstones (Fig. 5B). The thicknesses of the lamina-sets vary from a few centimetres up to several decimetres, whereas layers of SI lithofacies usually consist of cosets that can be up to several metres thick (Fig. 3G). The sediments of this lithofacies are usually interbedded with massive sandstones and conglomerates, and as members of a fining upwards sequence, they are overlain by ripple-laminated sandstones. Only in a few cases the upper boundary is sharp where the mudstones of the $\mathrm{Mm}$ and Mh lithofacies were observed directly over cross-bedded sandstones. Locally erosional surfaces exist where the SI lithofacies is overlain by conglomerates and a strong lithological contrast is observed. In some places, primary current lineation is visible (Fig. 5C), suggesting a NNW-SSE transport direction. The SI lithofacies either indicates distinct bedform geometries like washed-out dunes or humpback dunes occurring at the transition between subcritical and supercritical unidirectional flow or may represent plane beds developed on initially dipping surfaces, such as scour hollows.

Massive sandstones $(\mathrm{Sm})$. Massive conglomeratic to fine-grained sandstones are the second most frequent $(25 \%)$ among all lithofacies. In mesoscopic scale, no sedimentary structures can be distinguished, the rocks being perceived as generally massive (Fig. 5D). The thickness of this lithofacies changes in a broad range from single centimetres up to $3.5 \mathrm{~m}$ (Fig. $3 \mathrm{H}$ ). The boundaries are usually designated arbitrarily, except for those places where a strong lithological contrast is observed. Only locally the erosional surfaces at the contact of similar fraction occur. The massive sandstone bodies are interpreted as the product of subaqueous gravity flows (Jones and Rust, 1983; Rust and Jones, 1987; Turner and Monro, 1987; Wizevich, 1992), braid bar dissection by redirection of current flow (Hodgson, 1978), or as the result of channel bottom sedimentation during peak flow events (Conaghan and Jones, 1975; Conaghan, 1980; Wizevich, 1992). Thus, the massive sandbodies are believed to be the deposits of highly concentrated sediment/water mixtures which lie in the continuum from cohesionless sediment flow to stream flow with normal sediment concentration. The massive sediments are compositionally identical to the structured sandstones with which they are associated and they are interpreted as the result of deposition from highly concentrated stream flows developed through flooding and entrainment of sandy floodplain material (Martin and Turner, 1998). Sediment deposition occurred directly from rapid suspension fallout from a traction carpet, thus precluding the development of bedforms. The sandbody geometry of the massive sandstones is interpreted to be controlled by the interrelation of climate and sediment supply. To produce highly concentrated open channel flows, large quantities of suspended sediments are required. Modern hyperconcentrated flows occur in areas with high soil erosion and low vegetation cover. The Devonian-Cretaceous time interval was a period of increasing stabilization of land surfaces by vegetation and soil erosion is inferred to have been greater prior to the Cretaceous, when interfluve and upland areas started to be colonized by plants capable of surviving severe weather and climatic fluctuations (Miall, 1996). Finally, with the appearance of grasses during the Cenozoic Era, the relations between climate, vegetation, erosion, and runoff became much as today (Schumm, 1968), but hyperconcentrated flows are present even in humid climatic conditions with well-developed vegetation driven by torrential flood and heavy water runoff or bank erosion as well as by tectonic factors (e.g., earthquakes affecting water-laden deposits) (Costa, 1984; Guzzetti et al., 2008; Norhidayu et al., 2016; Widera, 2017).

Clast-supported conglomerates with abundant matrix $(\mathrm{Gm})$. This lithofacies contains poorly sorted massive as well as crudely horizontally laminated and crudely cross-bedded conglomerates (Fig. 6A). The matrix of these conglomerates is composed of coarse to very coarse-grained sandstones. Most of the clasts contain isometric quartz grains up to $5 \mathrm{~cm}$ in diameter, although some include infrequent chert and quartzite particles of granule and pebble size as well as elongated mudstone and fine-grained sandstone intraclasts up to $10 \mathrm{~cm}$ long. The quartz grains are mostly angular and subangular, with a small admixture of subrounded particles. The thickness of this lithofacies is highly variable from $5 \mathrm{~cm}$ to $4 \mathrm{~m}$ although it usually reaches $>30 \mathrm{~cm}$ (Fig. 3I). The lower boundaries of this lithofacies are usually erosional, especially in the lower part of the succession (see Fig. 7) In contrast, the upper boundaries are either sharp, if the distinct lithological contrast occurs, or gradational, if the only faint grain-size variations occur. This type of deposit can be either related to braided channels developed at the top of alluvial fans, catastrophic floods, braided river systems, or even to a meandering channel pattern (Steel and Thompson, 1983). The coarseness, poor sorting and abundant matrix in the conglomerates as well as the structure of the lithofacies suggest rapid deposition of sand and pebbles from a flow of high concentration (Steel and Thompson, 1983). However, they may also be related to braided streams forming longitudinal, diagonal or transverse bars (Rust, 1978), that may be internally complex (Bluck, 1976).

Clast-supported conglomerates (Gc). This lithofacies contains both well and poorly sorted isometric grains of granuleto pebble-size (Fig. 6B). The isometric shape of the grains obscures the sedimentary structures, but the crudely visible imbrication of more elongated clasts suggests a horizontal stratification. The clast inventory is similar to that of the $\mathrm{Gm}$ lithofacies with predominant quartz grains, but the grain sizes are typically smaller. Well-sorted granule and small (up to $1 \mathrm{~cm}$ ) pebble-sized clasts are most abundant, being usually angular and subangular, with only a portion being subrounded. The thickness of this lithofacies changes from $2 \mathrm{~cm}$ (almost single lamina scale) up to $80 \mathrm{~cm}$ and only one layer is thicker than that (Fig. 3J). This lithofacies is relatively rare within the whole succession (3.6\%). The lower boundaries are usually eroded, but where the grain-size is small, the boundaries are sharp or even gradational. The upper boundaries are mostly gradational while this facies passes into the coarse- to very coarse-grained sandstones of the Sm and SI lithofacies. Only in a few cases do mudstones occur directly over clast-supported conglomerates. This lithofacies is interpreted as a lag deposit or as longitudinal bedforms. The thicker beds probably represent gravelly low-relief longitudinal bars variously infiltrated with sand (see Miall, 1977; Nemec and Postma, 1993), whereas thinner layers are 

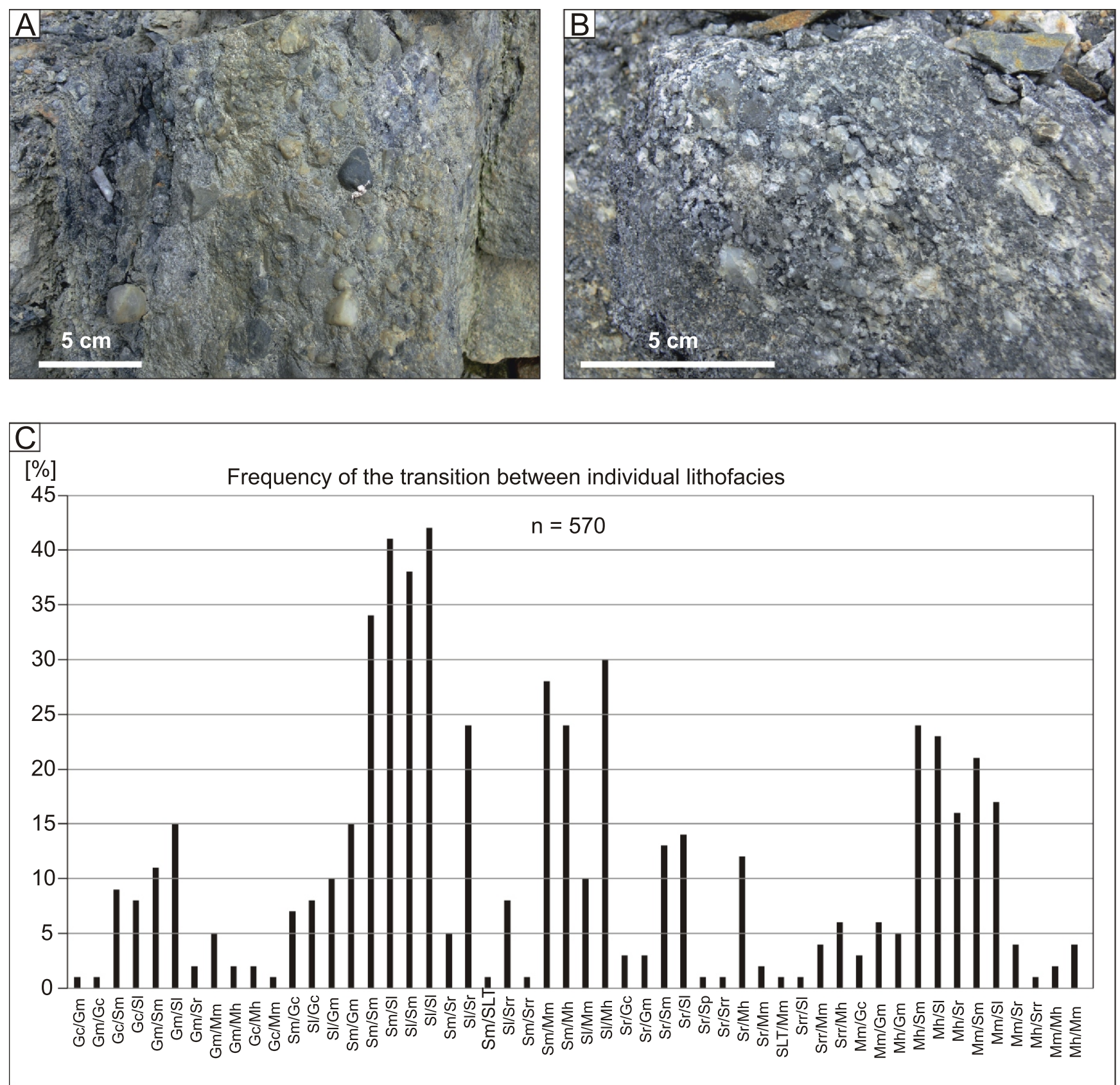

Fig. 6. Conglomeratic lithofacies (A, B) and (C) frequency of the transition between individual lithofacies

A - clast-supported conglomerates with abundant matrix $(\mathrm{Gm})$ lithofacies composed of pebble- to granule-sized vein quartz and an admixture of other lithic grains; B - clast-supported conglomerates (Gc) lithofacies containing angular pebble-

to granule-sized grains of vein quartz

interpreted as channel-floor lag deposits. The bars were probably formed shortly after channel incision, at the stage of highest flow power and gravel transport. The lack of high-angle cross-stratification suggests an absence of transverse or oblique braid bars (cf. Steel and Thompson, 1983; Miall, 1996).

\section{VERTICAL LITHOFACIES TRANSITIONS}

Analysis of the transition frequency between individual lithofacies (Fig. 6C) reveals that the most frequent transitions occur between the sandy lithofacies Sm/SI (41) and SI/SI (42), less commonly been observed between SI/Sm (38) and Sm/Sm (34) lithofacies. The second cluster of the most frequent transition is observed at sandstone/mudstone lithofacies changes SI/Mh (30), Sm/Mm (28) and Sm/Mh (24). The third cluster is composed of muddy and sandy lithofacies, which are less common in comparison with others, but this can be explained by the relatively low amount of fine-grained deposit within the whole section (see Fig. 3). The transition between horizontally laminated mudstones and sandstones (Mh/Sm, Mh/SI) occurs 24 and 23 times respectively, whereas the passage from massive mudstones into sandstone lithofacies is less common $(\mathrm{Mm} / \mathrm{Sm}-$ 21 and $\mathrm{Mm} / \mathrm{SI}-17)$. The last cluster is represented by transitions from conglomerates ( $\mathrm{Gc}$ and $\mathrm{Gm}$ lithofacies) into sandstones (Sm and $\mathrm{SI}$ ) lithofacies with frequencies of less than 15 each. 

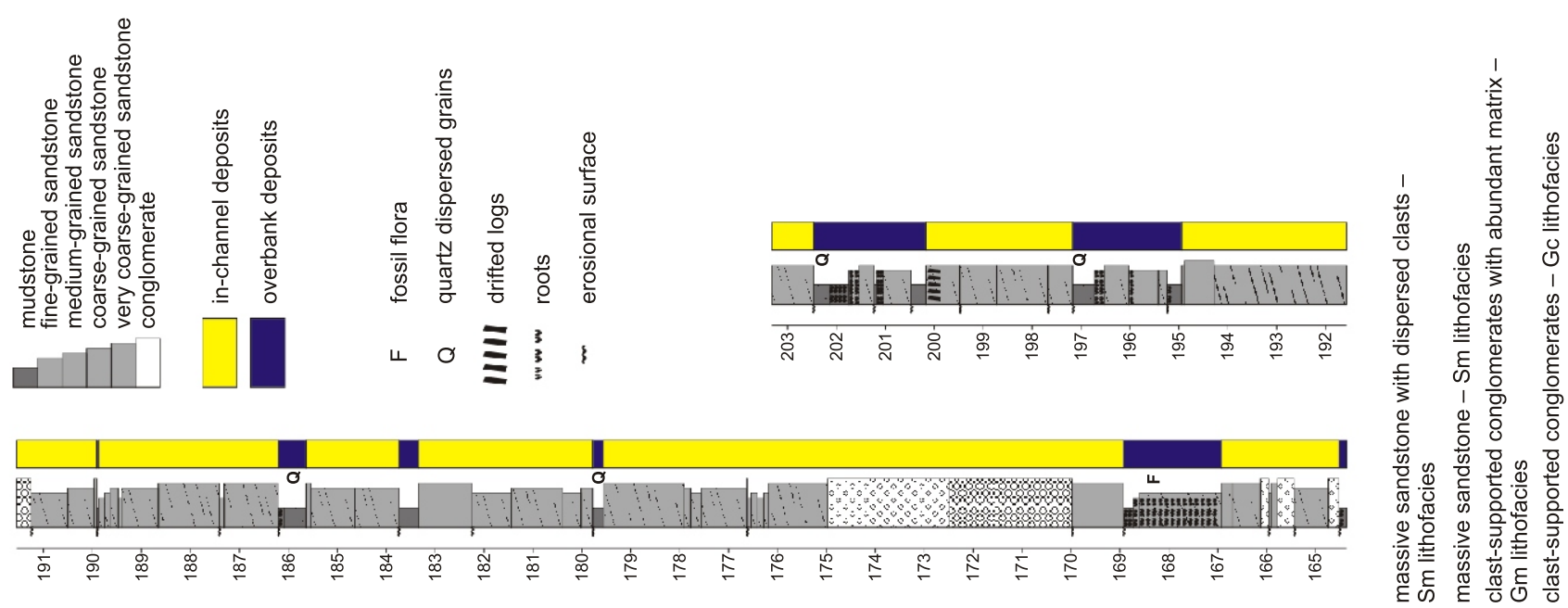

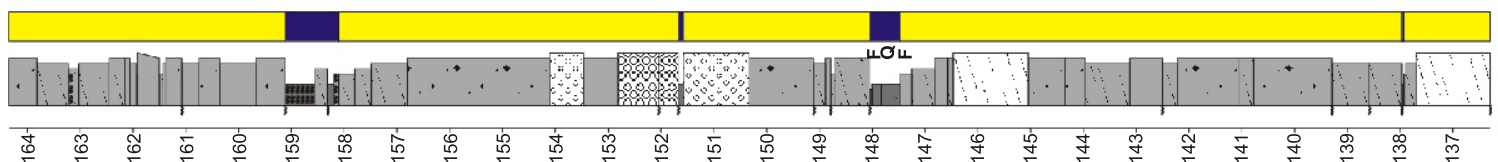
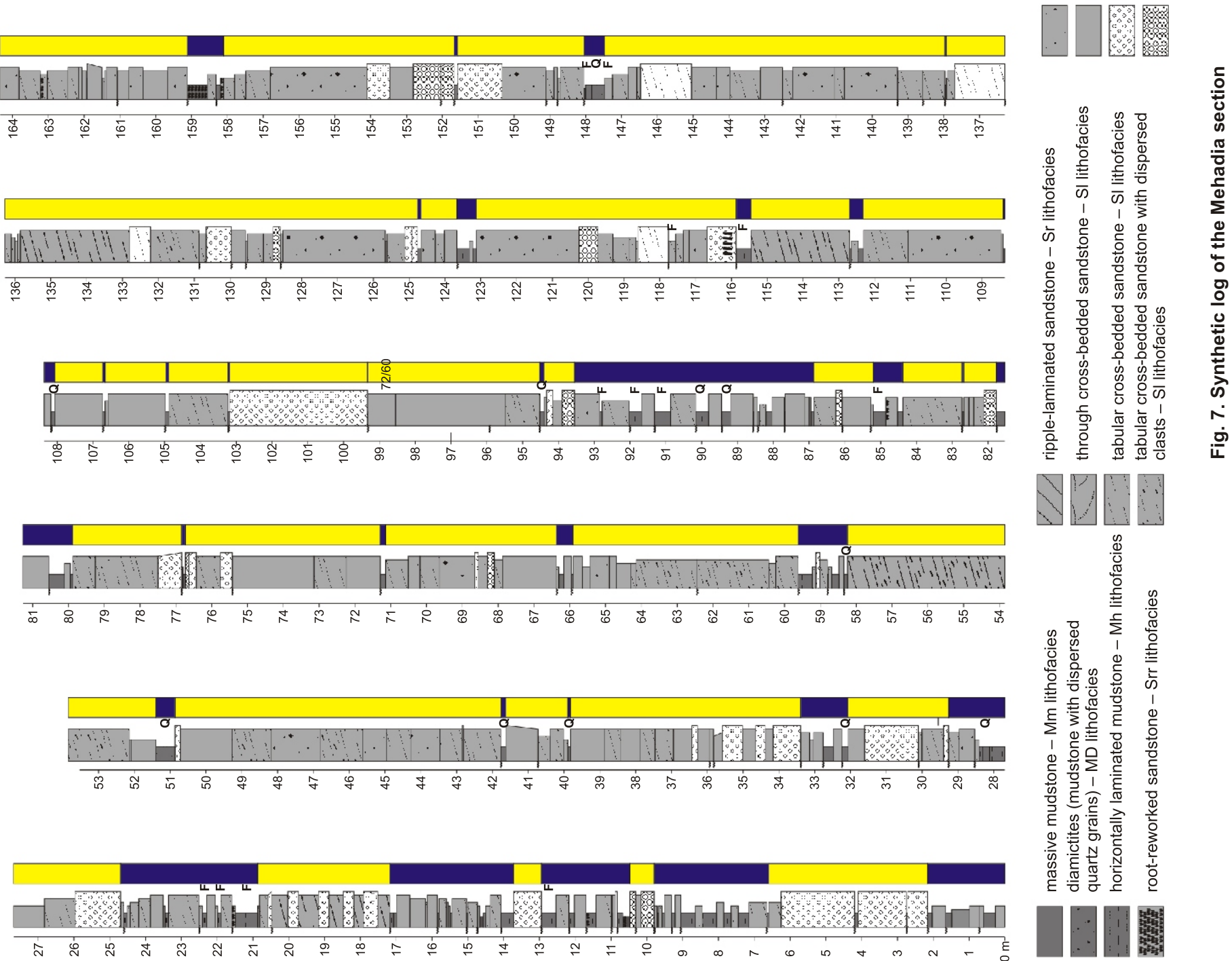

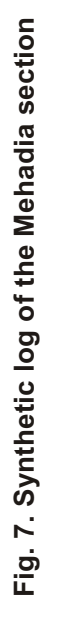

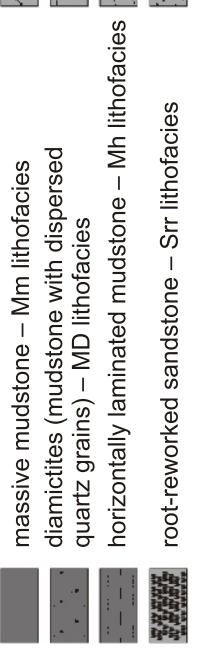


The most abundant transitions reflect either the frequency of the sandy lithofacies in the Mehadia section and changes in flow strength, or flow velocity fluctuation. The most frequent SI/SI transition indicates short-term breaks in deposition, which might be related to increase in flow velocity causing omission or even internal erosional surfaces. Almost the same frequency of the transition $\mathrm{Sm} / \mathrm{SI}$ from weakly organized to better structured deposits with less matrix is generally indicative of a decreasing flow strength and better hydrodynamic sorting of the particles. The abundance of the transitions between $\mathrm{SI} / \mathrm{Sm}$ and $\mathrm{Sm} / \mathrm{Sm}$ lithofacies can be explained by periodic and local sediment gravity flows (Jones and Rust, 1983; Rust and Jones, 1987; Turner and Monro, 1987; Wizevich, 1992), typically related to braid-bar incision (Hodgson, 1978) or bank collapse (Miall, 1996). The passages from sandstones lithofacies into both massive and laminated mudstones reflect a sudden drop in flow velocity and the deposition of suspended fine-grained material. The occurrence of the Mh lithofacies indicates the persistence of flow and suggest that the topmost parts of the bedforms were still covered by water, whereas massive mudstones indicate rapid emergence of the bar top and deposition from suspension in pools of standing water. The mudstones are mainly followed by sandstones, with the gravelly lithofacies occurring only rarely. The high lithological contrast between mudstones and structured medium-grained to conglomeratic sandstones suggests a rapid flooding of the overbank areas and that the flooding was strong enough to cause erosion of previously deposited mudstones. The transition from the both muddy lithofacies (Mh $\mathrm{Mm}$ ) to massive sandstones (Sm) can be explained by the deposition of material from eroded banks and their subsequent collapse producing locally hyperconcentrated flows, although it is possible that transitions of $\mathrm{Sm} / \mathrm{Mm} / \mathrm{Sm}$ lithofacies can also be explained by liquefaction of water-laden sediments and related to earthquakes. The typical transitions between conglomerates and overlying sandy deposits $(\mathrm{Gm} / \mathrm{SI}, \mathrm{Gm} / \mathrm{Sm}$ and $\mathrm{Gc} / \mathrm{Sm}$, $\mathrm{Gc} / \mathrm{SI}$ ) may reflect decreasing water depths over the growing bedform, which leads to decreased shear stress and to a corresponding upwards reduction in clast size (Miall, 1996). Some gravelly bedforms show segregation of gravel and sand within the same bedform. Well-sorted sands form topset beds, and bottomset beds composed of cross-bedded gravel show a continuation of bedding from the gravel up into the sand. Although gravel clasts according to Miall (1996) should be rounded to facilitate sorting by rolling on the bed, is it possible that the isometric shape of the clasts, despite their roundness, would be sufficient to support rolling. Bedforms with such features develop under plane-bed conditions (Miall, 1996).

The interpretation of the most frequent transitions within the Mehadia section leads to the conclusion that, during the deposition of coarse-grained material, relatively stable flow conditions prevailed, with only minor fluctuations, producing changes in sedimentary structures or/and subtle grain-size variations. The more prominent changes are related to periodic decrease and increase in flow velocity being responsible for the strong lithological contrasts between individual beds and they can be interpreted as switching between in-channel and overbank deposition or as a sudden drop and rise of the water-table level within the channel. Both processes are characteristic of the braided river environment.

\section{LITHOFACIES ASSOCIATIONS}

Fine-grained association (FA1). This lithofacies association is composed of mudstones (lithofacies Mm, Mh and MD) and of various sandstone fractions (mainly fine- to mediumgrained Sr, Srr and SI lithofacies). The thickness of the deposits attributed to this association is highly variable, from a few centimetres up to $>6.5 \mathrm{~m}$ (Fig. 7). The total content of the FA1 deposits is $\sim 20 \%$. In almost all cases, erosional surfaces have been observed at the upper boundaries. The analysis of the vertical sequence of the lithofacies allows the recognition of several depositional subenvironments related to overbank areas. Within gravel- and sand-bed river systems the overbank areas occupy only a minor part of the alluvial valley (e.g., Reinfels and Nanson, 1993).

Natural levee deposits (LV). These deposits occur especially in the lower part of the succession (Fig. 7). They are composed of interbedded horizontally laminated mudstones (Mh lithofacies) and fine-grained ripple-laminated sandstones ( $\mathrm{Sr}$ lithofacies). Traces of coalified root systems were sporadically observed. The thickness of the individual beds is relatively low $(5-40 \mathrm{~cm})$, and the levee bedsets can reach $1.9 \mathrm{~m}$ in thickness (Fig. 8A), although it is usually $<1 \mathrm{~m}$ (Fig. 8B-F). This set of features is typical of the natural levee subenvironment, although some parts can be also interpreted as various parts of the floodplain with crevasse splays (Fig. 8A, F). The definition given by Brierley et al. (1997) emphasized four components: (a) proximity to channel margin; (b) adjacent to active prismatic bodies, triangular in cross-section, ridge or wedge-shaped features, raised above the adjacent floodplain, as the basal contact may be poorly defined; (c) ribbon-like, elongate features, aligned parallel to channels; (d) elevation is greater at or close to the edge of the channel, where they commonly form steep banks, and from where they gently slope away into the floodbasin at some distance from the channel. This happens when the channel margin slope is better defined than the floodplain (distal) margin, as the levee may grade into adjacent floodplain units. In most cases, levees are composed of thinly interbedded flood-cycle deposits that reflect sedimentation influenced by an rising and falling water-table with each sedimentary rhythm representing a flood event. Upward-coarsening sequences are common, reflecting an increased bed shear stress related to rising flood events (e.g., Wizevich, 1992). During the high stage of the floodwater, levees are only occasionally covered by water and they typically have vegetated surfaces. Accordingly, their deposits may have a significant proportion of roots and organic matter (Brierley et al., 1997).

Crevasse channel and crevasse splay deposits (CR-S). Within the FA1 association there are sequences starting with erosional surfaces being characterized by an almost complete lack of conglomerates. A basal member is composed mainly of very coarse- to coarse-grained sandstones of the Sm and SI lithofacies, in many instances directly overlain by mudstones of the Mh lithofacies (Fig. 9). The maximum thickness of isolated sandstone beds (Fig. 9A) typically ranges from 20 to $40 \mathrm{~cm}$ and never exceeds $85 \mathrm{~cm}$. Subordinate coarsening-upwards sequences have been observed (Fig. 9B). Such sequences start with fine- to medium-grained sandstones of the $\mathrm{Sr}$ or $\mathrm{SI}$ lithofacies, with sporadic erosional surfaces at the base, and they gradually pass into coarser sediments, mainly of the SI lithofacies. The thickness of those sequences is typically $<0.5 \mathrm{~m}$. In a few cases, finning-upwards sequences occur (Fig. 9C) but only occasionally were pensymmetrical-like sequences identified (Fig. 9D). The fining-upwards sequences are thinner than the coarsening ones, and they do not exceed several tens of centimetres. The pensymmetrical-like type is characterized by coarsening of the upper sediment fraction followed by a gradual decrease in grain size. The thickness of the deposits reaches $>1.0 \mathrm{~m}$. Both sequences start with coarse- to very coarse-grained sandstones of the SI lithofacies and an erosional surface always occurs at the base of the lowermost member sequence. 

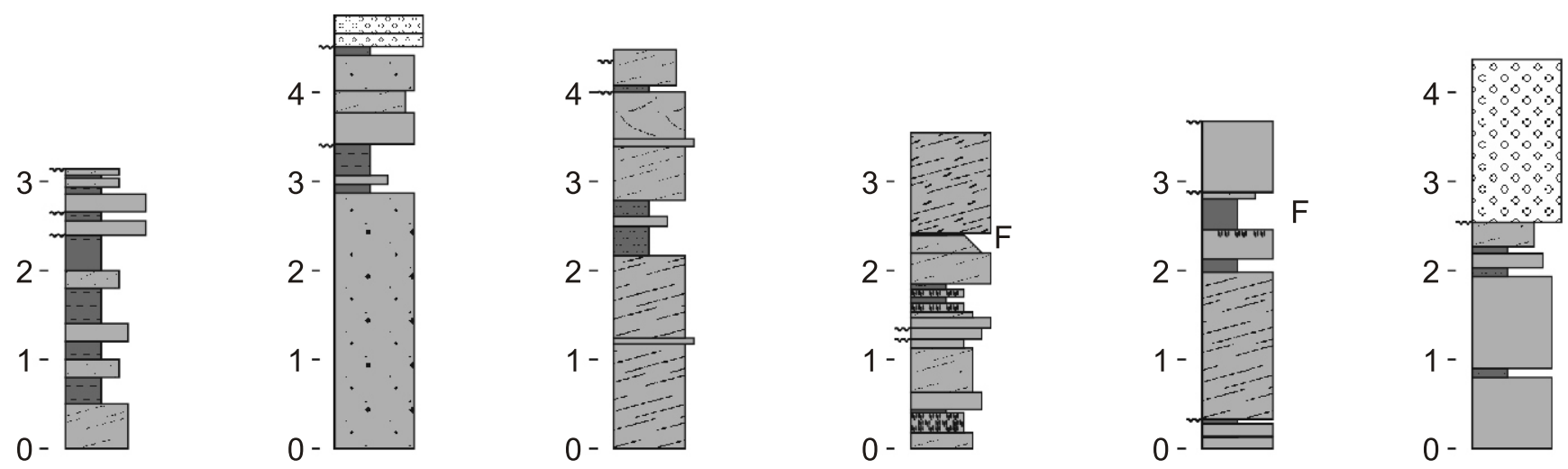

massive mudstone - Mm lithofacies diamictites (mudstone with dispersed quartz grains) - MD lithofacies horizontally laminated mudstone Mh lithofacies

root-reworked sandstone Srr lithofacies

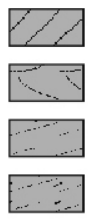

ripple-laminated sandstone -

Sr lithofacies

trough cross-bedded sandstone -

SI lithofacies

tabular cross-bedded sandstone -

SI lithofacies

tabular cross-bedded sandstone with

dispersed clasts - SI lithofacies

mudstone

rained sandstone

medium-grained sandstone

coarse-grained sandstone

very coarse-grained sandstone

conglomerate

$F$ fossil flora $Q$ quartz dispersed grains

massive sandstone with dispersed

clasts - Sm lithofacies

massive sandstone - Sm lithofacies

clast-supported conglomerates with abundant matrix - $\mathrm{Gm}$ lithofacies

clast supported conglomerates -

$\mathrm{Gc}$ lithofacies

\section{Fig. 8. Natural levee}

A - interbedding of the Mh and fine- to medium-grained $\mathrm{Sr}$ and $\mathrm{Sm}$ lithofacies that may be also interpreted as distal crevasse splay deposits; B, C - natural levee deposits cut off by crevasse channel deposits with pensymmetrical-like arrangement; D, E - natural levee deposits with dense coalified root system (Srr lithofacies) interbedded with mudstones; F - interbedding of the Mh and medium- to coarse-grained Sm and $\mathrm{SI}$ lithofacies that may be also interpreted as proximal crevasse splay deposits; vertical scale in metres

The common features of all these sequences are the reduced thickness (decimetres up to $1.5 \mathrm{~m}$ ) in comparison with in-channel deposits; the grain-size is distinctly smaller than in the thicker conglomeratic and sandy beds; the occurrence of sedimentary structures (ripple lamination and large scale cross-bedding in medium- to fine-grained sandstones - Sr and SI lithofacies), and the sharp or sporadically erosional lower bounding surface are typical of deposition from weaker flow; and the widespread occurrence of the root systems.
A

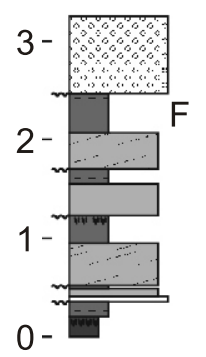

B

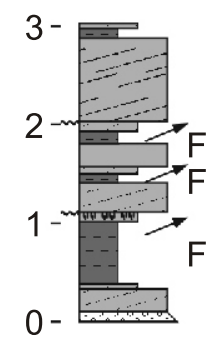

C

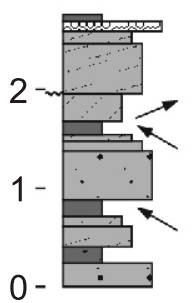

$\mathrm{D}$

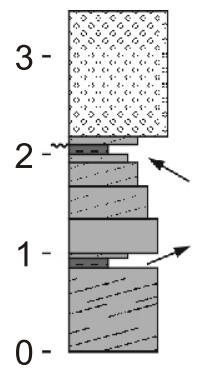

Fig. 9. Crevasse channels and crevasse splays

A - isolated sandstone bodies of the crevasse channels; B - coarsening upwards sequences of the crevasse deposits; $\mathbf{C}$ - fining upwards sequences; D - pensymmetrical-like arrangement of the crevasse deposits; arrows mark trends of grain-size increase or decrease; vertical scale in metres; explanations as in Figure 8
The assemblage suggests these sequences are crevasse channel and crevasse splay deposits. The channels are incised into levee and other overbank or backswamp deposits, becoming shallower away from the main channel and carrying finer material due to decreased flow velocity away from the main channel and toward the limits of the splay (Miall, 1996). The fining-upward sequences may be interpreted as the gradual passage from crevasse channel to crevasse splay deposits. The sediment was introduced in floodplain areas by crevasse channels and it was deposited as a result of flow expansion and of flow velocity decrease. The most distal parts of the crevasse splays are places of deposition for the most fine-grained material, as this material may indicate the most distal floodplain facies, including deposition in floodplain ponds.

Coarse-grained association (FA2). The sediments of the coarse-grained association include mainly medium- to very coarse-grained sandstones of the Sm and SI lithofacies and subordinate fine- to medium-grained sandstones of the $\mathrm{Sr}$ lithofacies, as well as matrix-rich $(\mathrm{Gm})$ and clast-supported conglomerates (Gc). The thickness of the coarse-grained packages varies from $2.5 \mathrm{~m}$ to $11.5 \mathrm{~m}$ (see Fig. 7). The cross-bedded and massive sandstone lithofacies predominate within the FA2 association with its total content exceeding $70 \%$. Usually interbedding between these two lithofacies occurs, although the SI lithofacies is slightly more abundant (see Fig. $3 \mathrm{~A}, \mathrm{G}, \mathrm{H}$ ) and the total thickness is markedly greater (103 m vs. $85 \mathrm{~m}$ ). The mean grain-size of the $\mathrm{Sm}$ lithofacies is more coarse-grained than the SI lithofacies and it contains a greater mixture of pebble-sized quartz and other lithic grains. Within the packages of 

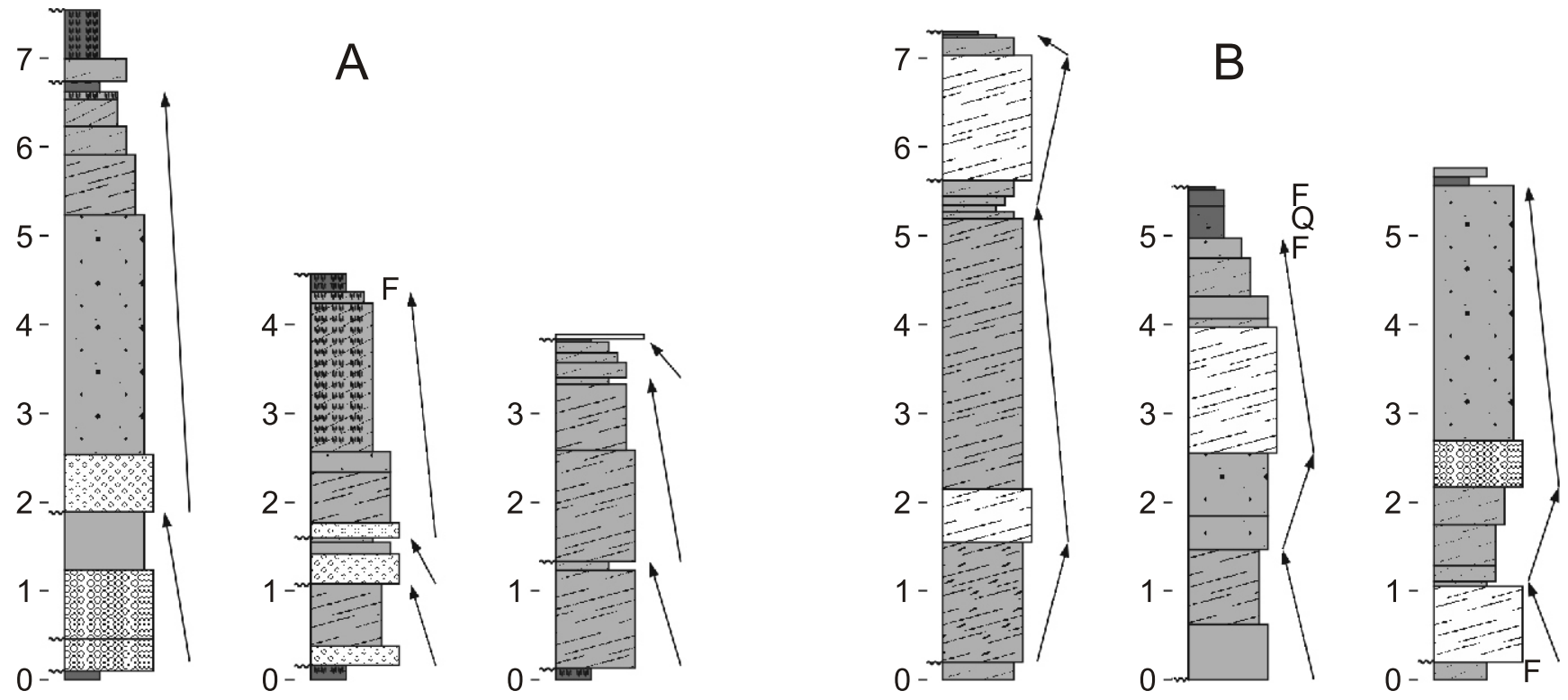

Fig. 10. In-channel sequences of the coarse-grained association

A - fining-upwards sequences; B - pensymmetrical sequences; arrows mark trends of grain-size increase or decrease; vertical scale in metres; explanations as in Figure 8

the FA2 association conglomerates also occur, both clast- and matrix-supported. The location of the conglomeratic layers shows no regular arrangement. The lower boundaries of the coarse-grained association are sharp and in places marked with erosional surfaces. Towards the top, grain-size rapidly decreases as a transition from very coarse- to coarse-grained ( $\mathrm{Sm}$ and $\mathrm{SI}$ lithofacies) through medium- to fine-grained (SI and $\mathrm{Sr}$ lithofacies) sandstones. They are capped with root-reworked sediments (Srr lithofacies) and mudstones ( $\mathrm{Mh}$ and $\mathrm{Mm}$ lithofacies). The finning-upward sequences (Fig. 10A) are not common and pensymmetrical-like sequences (Fig. 10B) occur only exceptionally. The thickness of the fully developed fining-upward sequences (erosional surface-Gc/Gc/Sm-SI$\mathrm{Sr}-\mathrm{Mh} / \mathrm{Mm}$ ) attains $4.8 \mathrm{~m}$, reflecting gradual decrease of the flow velocity. In many places, the coarse-grained association deposits are interbedded with thin (several centimetres), massive and laminated mudstone layers. This feature may be explained by a rapid decrease of the water table and subsequent filling of the local depressions developed at the top of the emergent bedform. Internal erosional surfaces are common within the FA2 association and they subdivide this unit into smaller intervals. The clast inventory of the FA2 association is rather poor and it contains the most resistant material i.e. quartz, quartzite and chert grains and to a lesser extent local sandstone and mudstone intraclasts. Typically, the grains are angular and subangular, and only occasionally subrounded.

The overall sedimentary structures and the vertical sequences of the coarse-grained association suggest deposition within fluvial channels with bedload dominance. The low content of clastic fines and the relatively high contribution of conglomerates suggest a gravel-dominated fluvial system. A detailed definition of architectural elements was impossible because the exposed faces were small. The interpretation of the lithofacies succession is descriptive in terms of variation (increasing or decreasing) of flow velocity. The sequences of the FA2 association that start with the $\mathrm{Gc}$ lithofacies, which are interpreted as the lag deposits and longitudinal gravel bars, represent the deepest part of the channels. Assuming a constant flow depth, the finning-upward order of the lithofacies suggests decreasing flow velocity and development of sandy bedforms of various types: longitudinal bars, washed-out dunes and humpback dunes. The interbedding of the massive, mostly conglomeratic, and very coarse-grained structured (being slightly finer) sandstones is the most common feature of the succession. The massive deposits are commonly linked to a mudclast breccia and/or to a massive sandstone with crude laminae developed parallel to the basal scour margin (Martin and Turner, 1998). The local, small-scale gravity flows can be related to fluvial bank and/or bar collapse. The low-angle cross-bedding is usually related to washed-out and humpback dunes. The recurrence of the massive and stratified sandstones reflects rapid changes of flow competence. The presence of erosional surfaces at the base of massive deposits are indicative of flood crests, whereas overlying cross-bedded sandstones of the washed-out dunes are related to the transition between upper and lower flow regime (Simons and Richardson, 1966) reflecting initial phases of falling flood level. The massive sandstones that lack erosional surfaces may be a result of bank or bar collapse.

The fully developed fining upwards sequences are not numerous, and packages of the coarse-grained association usually contain internal erosional surfaces. Sand body thickness is commonly used as a guide to original channel depth. The maximum thickness of the fully developed fining-upward sequence attains $4.8 \mathrm{~m}$ (see Fig. 10A) in the section studied, therefore it may be used as a proxy for channel depth.

\section{DEPOSITIONAL ENVIRONMENT OF THE MEHADIA SECTION DEPOSITS}

A variety of classifications of alluvial channels patterns have been created, but no satisfactory classification for the all researchers has yet been developed, despite attempts at refining existing ones. The classifications used sometimes mutually overlap and apply conflicting terminology (see Beechie et al., 2006). Fossil alluvial systems are usually not well exposed and generally do not offer deeper insight into detailed bar-form architectures. A simple classification based on vertical succes- 
sion of the lithofacies is sometimes preferred relating to the classification of Leopold and Wolman (1957) which encompasses braided, meandering, straight and anastomosing major patterns. In other classifications authors introduced the anabranching (both inactive and active laterally) term (Nanson and Knighton, 1996) and wandering (Church, 1983). For the Lower Jurassic deposits described from the Mehadia area, Miall's $(1977,1978,1996)$ classification seems to be the most appropriate, which allows the recognition of gravel- and sand-dominated rivers of low and high sinuosity as well as anastomosing fluvial systems. This classification also allows reference to the sedimentary succession of modern analogues.

We generally interpret the sediments studied in the Mehadia area (Greaţca and Ciumoasa valleys) as being deposited within a braided fluvial system composed of channel tracts and floodplains. A braided fluvial system is demonstrated by the dominance of coarse-grained deposits within the whole section and by the lesser content of overbank fines. The comparison with models of sediment sequences presented by Miall (1977, 1978 , 1996) points to the greatest similarity with a deep, gravel-bed braided river of Donjek type. This similarity is supported by the high amount of conglomerates and of conglomeratic sandstones, and also by the small content of trough cross-bedded sandstones. The deep, gravel bed braided rivers are characterized by several distinct topographic levels including major and minor channels, bar surfaces, and floodplains. This type of rivers is characterized by low to intermediate sinuosity, with a dominance of gravel bars and sandy bedforms. According to Miall $(1977,1996)$, four depositional levels were identified within the Donjek River: (1) a level of main channels and of principal sediment dispersal routes, with little or no vegetation, and with bars exposed only during low stage; (2) a level active during flood stages, with few active channels at other times, and sparse vegetation cover; (3) a level with ephemeral streams, low energy flow during flood stages, and with moderate vegetation cover; (4) a level with dry islands covered by dense vegetation. These four levels may represent stages of progressive down-cutting by the river itself, and they are most recognizable in areas undergoing active degradation. Because of the relatively small dimensions of the exposure, it is possible that the section studied may represent a gravel-bed meandering fluvial system (Miall's model 4) with one active channel and scattered bars and islands (Miall, 1985, 1996). But, as emphasised by Miall (1996), information about the floodplain of this river system is limited, with no detailed data whether or not crevassing and crevasse splays are common. Braided fluvial systems may have well-developed overbank areas, where thick packages of overbank fines accumulate (lelpi et al., 2014; Lojka et al., 2016) in places containing thick coal seams (Doktor, 2007; Kędzior, 2016). The area studied during Early Jurassic time was probably located near the tropics and a hot and wet climate was controlled by seasonal, monsoonal type heavy rainfall (Popa and Van Konijnenbrug-Van Cittert, 2006; Kędzior and Popa, 2013), thus rapid erosion and efficient runoff occurred only periodically. The study of modern mountain rivers performed by Beechie et al. (2006) often shows the rejuvenation of floodplain surfaces related to rivers of island-braided and braided channel pattern (mean age of floodplain surfaces 41 and 12 years respectively).

In other classifications, the Early Jurassic fluvial system described from Mehadia can be termed as laterally active systems of an anabranching system if braided or meandering channels were separated by vegetated semi-permanent islands (Nanson and Knighton, 1996). But, for the section studied, there is a lack of evidence that multiple channels were active simultaneously (see also Gibling et al., 2014). Some gravel rivers can be also defined as wandering gravel-bed rivers that are considered as transitional between meandering and braiding showing an irregular pattern of channel instability (Church, 1983) and characterized by multiple channels around islands, abandoned channels within the floodplains (Burge and Lapointe, 2005) while the individual anabranches surrounding islands are connected by single-thread channels showing braiding or meandering characteristics (Burge, 2005). On the other hand, evidence has been found that suggests the presence of dense vegetation (root-reworked sediments). Drifted logs can also be indicative of the presence of vegetated islands (Rust and Gibling, 1990; Fielding et al., 2009; Gibling et al., 2010; lelpi et al., 2014) and can also indicate wandering or island-braided rivers (Gibling et al., 2014).

The clast inventory of the conglomerates is very poor and consists exclusively of the mature, most resistant particles such as quartz, quartzite and chert. An admixture of intrabasinal lithic grains (sandstones and mudstones) also occurs in the Mehadia area. The shapes of the grains, mostly angular to subrounded, suggest that the clasts have not been subjected to multiphase deposition and reactivation processes. Therefore, we consider that the source area for the basin fill was closely located to the sedimentary basin and that the source rocks contained a large amount of quartz. The Lower Jurassic continental deposits in Mehadia area unconformably overlie granitoids, mica-schists, gneisses and rhyolites of the Danubian units, making these the potential source rocks.

\section{CONCLUSIONS}

This paper presents the results of the first sedimentological study of the Lower Jurassic deposits belonging to the Presacina Basin. The detailed palaeoenvironmental characteristics of the Early Jurassic of this region were unclear until now. This sedimentological study of the Hettangian-Sinemurian continental sediments leads to the following main conclusions.

1. The deposits studied in the Mehadia area are generally interpreted as deposited within a braided fluvial system composed of channel tracts and floodplains. Comparisons with models of sediment successions shows similar features to a deep, gravel-bed braided river, with low to intermediate sinuosity and dominant gravel bars and sandy bedforms (Donjek type of Miall, 1977, 1978, 1996), or with gravel meandering (Miall's type 4, 1985). Deep, gravel-bed braided rivers are characterized by several distinct topographic levels including major and minor channels, bar surfaces, and the floodplain, whereas gravel-bed meandering rivers are characterised by one main active channel with deposition occurring on large flat point bars and side-bar complexes (Miall, 1996).

2. The coarse-grained facies association (FA2) represents deposition within fluvial channels with bedload dominance. The sequences of the FA2 that start with gravelly facies are interpreted as: (1) the lag deposits or (2) the longitudinal gravel bars and represent the deepest part of the channel.

3. The subaqueous gravity flow and sedimentation during peak flow events are responsible for the formation of massive coarse- to very coarse-grained sandstones. The local, small-scale gravity flow deposits may also represent fluvial bank and/or bar collapse.

4. The normal, fining-upward order of the lithofacies suggests decreasing flow velocity. Fully developed fining-upwards sequences are not numerous. The fining-upward sand body thickness used as a guide to original channel depth indicates $\sim 5 \mathrm{~m}$ as the maximum depth for the channels in the Mehadia section. The fine-grained facies association (FA1) is considered 
to have been deposited on the floodplain areas and it represents several subenvironments as: (1) natural levee; (2) crevasse channel; (3) proximal and distal crevasse splay. The crevasse channels are incised into levee and into other backswamp deposits. The fining-upwards sequences are interpreted as the gradual passage from crevasse channel to crevasse splay deposits. The sediment was supplied to the floodplain area by crevasse channels being deposited as a result of flow expansion and decrease in flow velocity. The most distal parts of the crevasse splays are places of deposition for the most fine-grained material, including deposition in floodplain ponds. Thin mudstone interbeds within coarse-grained sediments are related to sedimentation in pools of standing water during low-stage channel abandonment, when the water table suddenly fell.

5. The clast inventory of the conglomerates consists of exclusively mature, most resistant particles such as quartz and also quartzite and chert, with a small amount of intrabasinal lithic grains, such as sandstones and mudstones. The mostly angular to subrounded shape of the grains suggests a relatively short distance of transportation. The source area for the basin fill was located close to the sedimentary basin and its source rocks contained large amount of quartz. The crystalline basement composed of granitoids and rhyolites of the Upper Danubian Units represent the potential source rocks.

Acknowledgements. The authors wish to thank the staff of Staicons Company for permission to undertake fieldwork in the Greaţca Quarry. We also thank S. Nehyba and an anonymous reviewer for their helpful comments. We would like to thank A. Wysocka, who helped to improve significantly the content of the manuscript. We thank B. Thomas (Aberystwyth University) for his kind help with improving the English of our manuscript. This paper is a result of the Romanian CNCSIS/NURC grant no. 436/2007 "Ecoter" to one of the authors (MEP). This paper is also a contribution of the IGCP 632 project.

\section{REFERENCES}

Beechie, T.J., Liermann, M., Pollock, M.M., Baker, S., Davies, J., 2006. Channel pattern and river-floodplain dynamics in forested mountain river systems. Geomorphology, 78: 124-141.

Berza, T., Krautner, H.G., Dimitrescu, R., 1983. Nappe structure of the Danubian window of the Central South Carpathians. Anuarul Institutului de Geologie şi Geofizică, 60: 31-34.

Berza, T., Balintoni, I., Seghedi, A., Hann, H.P., 1994. South Carpathians. Romanian Journal of Tectonics and Regional Geology 75 : 37-49.

Bluck, B.J., 1976. Sedimentation in some Scottish rivers of low sinuosity. Earth and Environmental Science Transactions of the Royal Society of Edinburgh, 69: 425-456.

Brierley, G.J., Ferguson, R.J., Woolfe, K.J., 1997. What is a fluvial levee? Sedimentary Geology, 114: 1-9.

Burge, L.M., 2005. Wandering Miramichi rivers, New Brunswick, Canada. Geomorphology, 69: 253-274.

Burge, L.M., Lapointe, M.F., 2005. Understanding the temporal dynamics of the wandering Renous River, New Brunswick, Canada. Earth Surface Processes and Landforms, 30: 1227-1250.

Church, M., 1983. Pattern of instability in a wandering gravel bed channel. IAS Special Publications, 6: 169-180.

Codarcea, A., 1940. Vues nouvelles sur la tectonique du Banat meridional et du Plateau de Mehedinţi. Annuaire de I'Institut Geologique de Roumanie, 20: 1-74.

Conaghan, P.J., 1980. The Hawkesbury Sandstone: gross characteristics and depositional environment. Geological Survey of New South Wales Bulletin, 26: 188-253.

Conaghan, P.J., Jones, J.G., 1975. The Hawkesbury Sandstone and the Brahmaputra: a depositional model for continental sheet sandstones. Journal of the Geological Society of Australia, 22 275-283.

Costa, J.E., 1984. Physical geomorphology of debris flows. In: Developments and Applications of Geomorphology (eds. J.E. Costa and P.J. Fleisher): 268-317. Springer, New York.

Dashtgard, S.E., Gingras, M.K., Butler, K.E., 2006 Sedimentology and stratigraphy of a transgressive, muddy gravel beach: Waterside Beach, Bay of Fundy, Canada. Sedimentology, 53: 279-296.

Doktor, M., 2007. Conditions of accumulation and sedimentary architecture of the upper Westphalian Cracow Sandstone Series (Upper Silesia Coal Basin, Poland). Annales Societatis Geologorum Poloniae, 77: 219-268.
Drăghici, C., Boiciuc, M., 1969. Orizontare litologică şi litogeneză în Formaţiunea de Schela, de la Schela. Studii si Cercetari de Geologie, Geofizica, Geografie Seria Geologie, 14: 423-449.

Fielding, C.R., Allen, J.P., Alexander, J., Gibling, M.R., 2009. A facies model for fluvial systems in the seasonal tropics and subtropics. Geology 37: 623-626.

Frakes, L.A., 1978. Diamictite. In: The Encyclopedia of Sedimentology (eds. R.W. Fairbridge and J. Bourgeois): 262-263. Dowden, Hutchinson and Ross, Stroudsburg.

Gheorghiu, C., 1958. Cercetări geologice în Valea Mehadia, la nord, şi Topleţ, la sud. Analele Universităţi C. I. Parhon, 18: 145-168.

Gheorghiu, C., Răileanu, G., 1957. Prezenţa Toarcianului în Valea Sfîrdinului la Mehadia - Banat. Analele Universităţii C. I. Parhon, 14: 205-211.

Gibling, M.R., Bashforth, A.R., Falcon-Lang, H.J., Allen, J.P., Fielding, C.R., 2010. Log jams and flood sediment buildup caused channel abandonment and avulsion in the Pennsylvanian of Atlantic Canada. Journal of Sedimentary Research, $\mathbf{8 0}$ : 268-287.

Gibling, M.R., Davies, N.S., Falcon-Lang, H.J., Bashforth, A.R., DiMichele, W.A., Rygel, M.S., lelpi, A., 2014. Palaeozoic co-evolution of rivers and vegetation: a synthesis of current knowledge. Proceedings of the Geologists' Association, 125: 524-533.

Guzzetti, F., Peruccacci, S., Rossi, M., Stark, C.P., 2008. The rainfall intensity-duration control of shallow landslides and debris flows: an update. Landslides, 5: 3-17.

Hodgson, A.V., 1978. Braided river bedforms and related sedimentary structures in the Fell Sandstone Group (Lower Carboniferous) of north Northumberland. Proceedings of Yorkshire Geological Society, 41: 509-532.

lancu, V., Berza, T., Seghedi, A., Gheuca, I., Hann, H.P., 2005. Alpine alaeosols tectono-metamorphic evolution of the South Carpathians: a new overview. Tectonophysics, 410: 337-365.

lelpi, A., Gibling, M.R., Bashforth, A.R., Lally, C., Rygel, M.C., Al-Siwaldi, S., 2014. Role of vegetation in shaping Early Pennsylvanian braided rivers: architecture of the Boss Point Formation, Atlantic Canada. Sedimentology, 61: 1659-1700.

Iliescu, O., 1963. Contributions a la connaisance des depots permiens et liassiques de Mehadia - region de Banat. V-eme Congres de l'Association geologique Carpatho-Balcanique, Bucureşti: 159-176. 
Iliescu, O., Semaka, A., 1962. Contribuţiuni la cunoaşterea Rheto-Liasicului din împrejurimile Mehadiei. Dări de Seamă ale Şedinţelor Comitetului Geologic, 48: 113-119.

Iliescu, O., Hinculov, A., Hinculov, I., 1968. Bazinul Mehadia. Studiu geologic şi paleontologic. Memorii, 9: 1-187.

Johns, B.G., Rust, B.R., 1983. Massive sandstone facies in the Hawkesbury Sandstone, a Triassic fluvial deposit near Sydney, Australia. Journal of Sedimentary Petrology, 53: 1249-1259.

Kędzior, A., 2016. Reconstruction of an early Pennsylvanian fluvial system based on geometry of sandstone bodies and coal seams: the Zabrze Beds of the Upper Silesia Coal Basin, Poland. Annales Societatis Geologorum Poloniae, 86: 437-472.

Kędzior, A., Popa, M.E., 2013. Sedimentology of the Early Jurassic terrestrial Steierdorf Formation in Anina, Colonia Cehă Quarry, South Carpathians, Romania. Acta Geologica Polonica, 63: 175-199.

Lojka, R., Rosenau, N.A., Sidorinova, T., Strnad, L., 2016. Architecture, palaeosols and cyclicity of the Middle-Late Pennsylvanian proximal fluvial system (Nýrany Member, Pilsen Basin, Czech Republic). Bulletin of Geosciences, 91: 111-140.

Leopold, L.B., Wolman, M.G., 1957. River channel patterns: braided, meandering and straight. U.S. Geological Survey Professional Paper. Survey, 282-B, Washington, DC.

Manolescu, G., 1932. Das Alter der Schela-Formation. Buletinul Societăţii Române de Geologie, 1, 169-175.

Martin, C.A.L., Turner, B.R., 1998. Origins of massive-type sandstones in braided river systems. Earth-Science Reviews, 44: 15-38.

Miall, A.D., 1977. A review of the braided river depositional environment. Earth-Science Reviews, 13: 1-62.

Miall, A.D., 1978. Lithofacies types and vertical profile models in braided river deposits: a summary. Canadian Society of Petroleum Geologists, Memoir, 5: 597-604.

Miall, A.D., 1985. Architectural-element analysis: a new method of facies analysis applied to fluvial deposits. Earth-Science Reviews, 22: 261-308.

Miall, A.D., 1996. The Geology of Fluvial Deposits: Sedimentary Facies, Basin Analysis and Petroleum Geology. Springer, Berlin.

Mrazec, L., 1898. Dare de seamă asupra cercetărilor geologice din vara anului 1897. I. Partea de est a munţilor Vulcan. Buletinul Ministerului Agriculturi si Domeniilor.

Munteanu-Murgoci, G., 1905. Sur l'existence d'une grande nappe de recouvrement dans les Carpathes meridionales. Comptes Rendus des Academie de Sciences, Paris, 7: 31.

Mutihac, V., 1990. Structura geologică a teritoriului României. Editura Tehnică, Bucharest.

Nanson, G.C., Knighton, A.D., 1996. Anabranching rivers: their cause, character and classification. Earth Surface Processes and Landforms 21: 217-239.

Nãstãseanu, S., 1980. Geologie des Monts Cerna. Anuarul Institutului de Geologie şi Geofizică, 54: 153-280.

Nãstãseanu, S., Cernjavska, S., 1980. New lithostratigraphic and palynological data regarding the eojurassic from Mehadia (southern Carpathians). Revue Roumaine de Geologie, Geophysique et Geographie, ser. Geologie, 24: 199-207.

Nãstãseanu, S., Bercia, I., lancu, V., Vlad, Ş., Hârtopanu, I., 1981. The structure of the South Carpathians (Mehedinţi - Banat Area). IGR, Bucureşti.

Nemec, W., Postma, G., 1993. Quaternary alluvial fans in southwestern Crete: sedimentation processes and geomorphic evolution. IAS, Special Publication, 17: 235-276.

Norhidayu, K., Kamarudin, A.T., Muhammad, M., Anuar, K., 2016. Triggering mechanism and characteristic of debris flow in
Peninsular Malaysia. American Journal of Engineering Research, 5: 112-119.

Popa, M.E., 2009. Late Palaeozoic and Early Mesozoic continental formations of the Reşiţa Basin. Editura Universităţii din Bucureşti, Bucharest.

Popa, M.E., Van Konijnenburg-Van Cittert, J.H.A., 2006. Aspects of Romanian Early-Middle Jurassic palaeobotany and palynology. Part VII. Successions and floras. Progress in Natural Sciences, 16: 203-212.

Reinfelds, I., Nanson, G., 1993. Formation of braided river floodplains, Waimakariri River, New Zealand. Sedimentology, 40: 1113-1127.

Rust, B.R., 1978. Depositional models for braided alluvium. Canadian Society of Petroleum Geologists, Memoir, 5: 605-626.

Rust, B.R., Jones, B.G., 1987. The Hawkesbury Sandstone south of Sydney, Australia: Triassic analogue for the deposit of a large braided river. Journal of Sedimentary Petrology, 57: 222-233.

Rust, B.R., Gibling, M.R., 1990. Braidplain evolution in the Pennsylvanian South Bar Formation, Sydney Basin, Nova Scotia, Canada. Journal of Sedimentary Petrology 60: 59-72.

Schafarzik, F., 1885. Das Gebirge zwischen Mehadia und Herculesbad im Komitate Krasso-Szoreny. Foldtani Kozloni, 15: 512.

Schafarzik, F., 1888. Notizen aus dem Mehadier Zuge des Krasso Szorenyer Gebirges. Jahresbericht der Königlichen Ungarischen Geologischen Anstalt: 122-132.

Schafarzik, F., 1889. Daten zur Geologie des Cserna Thales. Jahresbericht der Königlichen Ungarischen Geologischen Anstalt: 142.

Schloembach, V., 1869. Die Umgebung von Pettnik, Mehadika, Pattasch, und Prigor im Rumanisch Banater Grenzregiment Verhandlungen der Geologischen Bundesanstalt: 212-215.

Schreter, Z., 1911. Bericht uber die im Neogengebiet von Orşova und Mehadia-Kornya vorgenommenen geologischen Untersuchungen. Jahresbericht der Königlich Ungarischen Geologischen Reichsanstalt: 122-128.

Schumm, S.A., 1968. Speculations concerning paleohydrologic controls of terrestrial sedimentation. GSA Bulletin, 79: 1573-1588.

Semaka, A., 1969. Studiul florei mezozoice din zona Mehadia. Institutul Geologic al României, Bucureşti unpublished geological report no. 59/1968, 28.

Semaka, A., 1970. Flora Rhaeto-Liasică de la Mehadia. Dări de Seamă ale Şedinţelor Comitetului Geologic, 56: 61-75.

Simons, D.B., Richardson, E.V., 1966. Resistance to flow in alluvial channels. U.S. Geological Survey Professional Paper, 422J.

Steel, R.J., Thompson, D.B., 1983. Structures and textures in Triassic braided stream conglomerates ('Bunter' Pebble Beds) in the Sherwood Sandstone Group, North Staffordshire, England. Sedimentology, 30: 341-367.

Turner, B.R., Monro, M., 1987. Channel formation and migration by mass-flow processes in the Lower Carboniferous fluviatile Fell Sandstone Group, northeast England. Sedimentology, 34: 1107-1122.

Widera, M., 2017. Sedimentary breccia formed atop a Miocene crevasse-splay succession in central Poland. Sedimentary Geology, 360: 96-104.

Wizevich, M.C., 1992. Sedimentology of Pennsylvanian quartzose sandstones of the Lee Formation, central Appalachian Basin: fluvial interpretation based on lateral profile analysis. Sedimentary Geology, 78: 1-47. 